

\section{U.S. Department of the Interior \\ KEN SALAZAR, Secretary}

\section{U.S. Geological Survey \\ Marcia K. McNutt, Director}

U.S. Geological Survey, Reston, Virginia: 2010

For product and ordering information:

World Wide Web: http://www.usgs.gov/pubprod

Telephone: 1-888-ASK-USGS

For more information on the USGS—-the Federal source for science about the Earth,

its natural and living resources, natural hazards, and the environment:

World Wide Web: http://www.usgs.gov

Telephone: 1-888-ASK-USGS

Suggested citation:

Wilson, J.T., comp., 2010, Fort Collins Science Center-Fiscal year 2009 science accomplishments: U.S. Geological Survey Open File Report 2010-1148, 47 p.

Any use of trade, product, or firm names is for descriptive purposes only and does not imply endorsement by the U.S. Government.

Although this report is in the public domain, permission must be secured from the individual copyright owners to reproduce any copyrighted material contained within this report. 


\section{Contents}

Introduction: Science for Natural Resources Management ............................................................................. 1

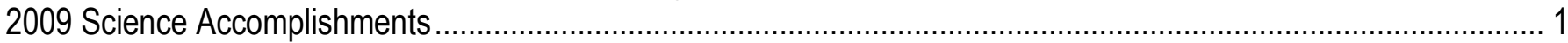

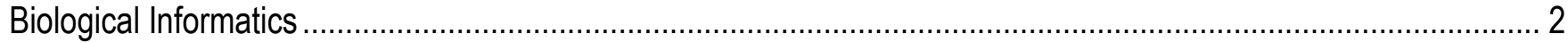

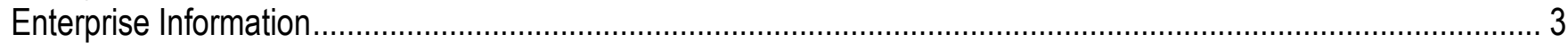

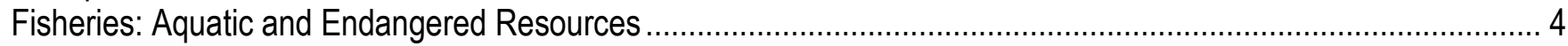

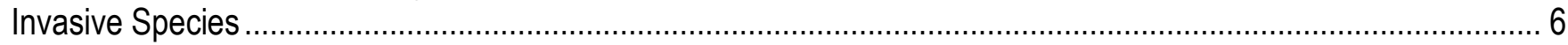

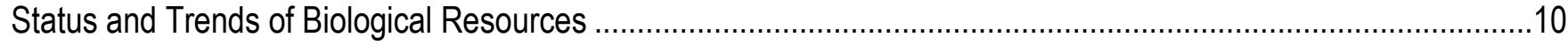

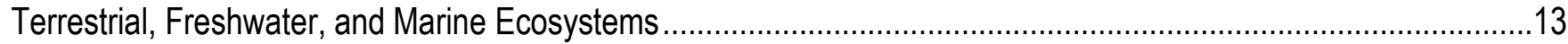

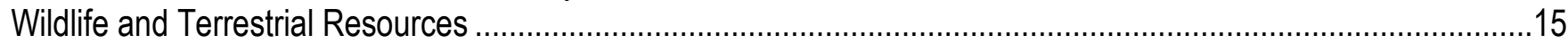

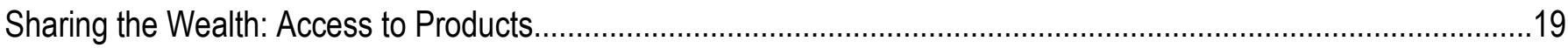

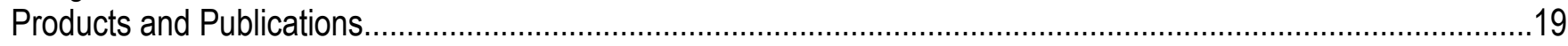

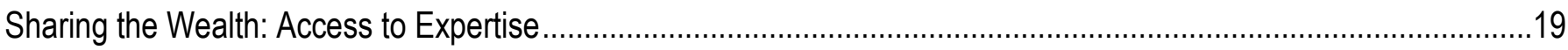

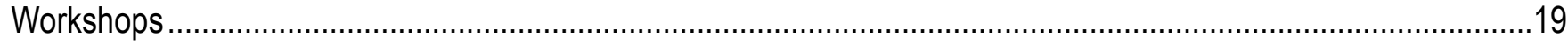

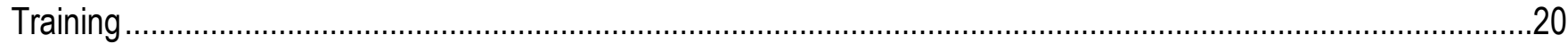

Making a Difference (Customer Satisfaction) ……..........................................................................................21

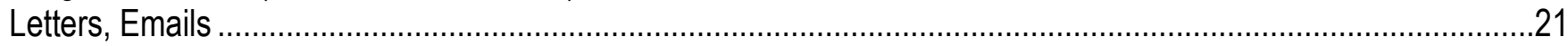

Non-USGS Awards ………………………………

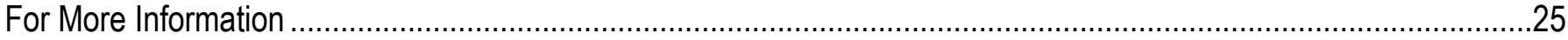

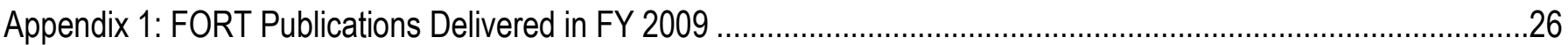

Appendix 2: Other FORT Products Delivered in FY 2009...........................................................................3

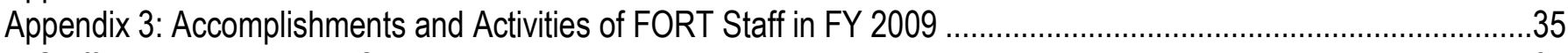

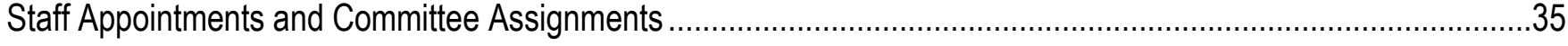

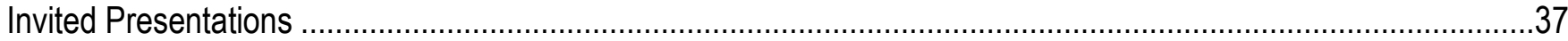

Appendix 4: USGS Science Strategy Directions and Programs Supported by 2009 FORT Scientific and Technical Accomplishments 


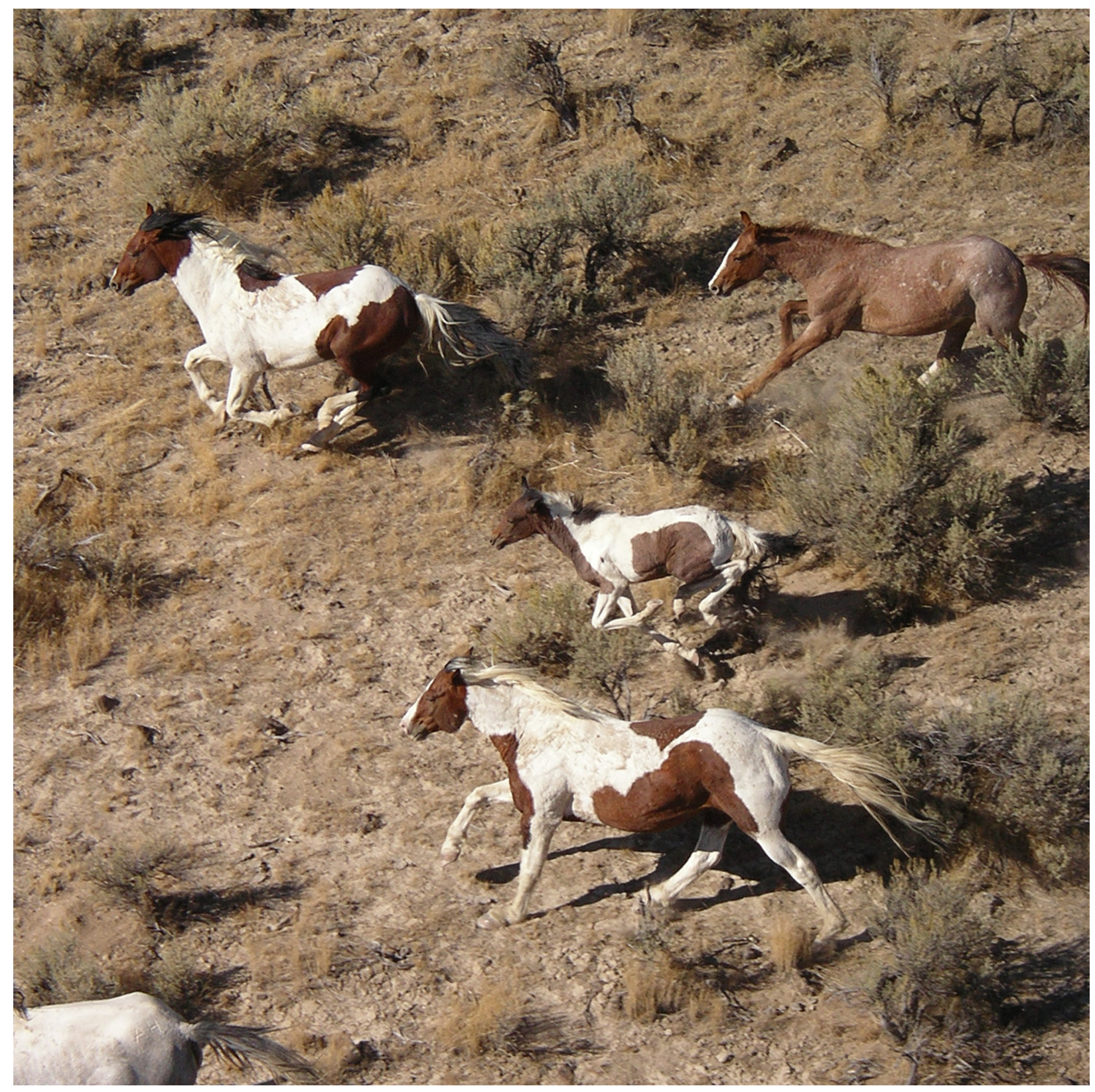

Wild horses in McCullough Peaks Herd Management Area near Cody, Wyo. USGS photo by Jason Ransom. 


\title{
Fort Collins Science Center Fiscal Year 2009 Science Accomplishments
}

\author{
Compiled by Juliette T. Wilson ${ }^{1}$
}

\section{Introduction: Science for Natural Resources Management}

Public land and natural resource managers in the United States are confronted with increasingly complex decisions that have important ramifications for both ecological and human systems. The scientists and technical professionals at the U.S. Geological Survey (USGS) Fort Collins Science Center (FORT) - many of whom are at the forefront of their fields - possess a unique blend of ecological, socioeconomic, and technological expertise. Because of this diverse talent, FORT staff are able to apply a systems approach to investigating complicated ecological problems in a way that helps answer critical management questions. In addition, FORT has a long record of working closely with the academic community through cooperative agreements and other collaborations. FORT is deeply engaged with other USGS science centers and partners throughout the Department of the Interior (DOI). As a regular practice, we incorporate the expertise of these partners in providing a full complement of "the right people" to effectively tackle the multifaceted research problems of today's resource-management world.

In Fiscal Year 2009 (FY09), FORT's scientific and technical professionals continued research vital to DOI science and management needs. FORT work also supported the science needs of other Federal and State agencies as well as non-government organizations. Specifically, FORT research and technical assistance focused on client and partner needs and goals in the areas of biological information management and delivery, enterprise information, fisheries and aquatic systems, invasive species, status and trends of biological resources (including human dimensions), terrestrial ecosystems, and wildlife resources. In the process, FORT science addressed natural-science information needs identified in the USGS Science Strategy (http://www.usgs.gov/science_strategy), including understanding and predicting change in ecosystems, climate variability and change, energy development and land management, the role of the environment and wildlife in human health, freshwater ecosystems, data integration, and evolving technologies. Several science projects were expanded in FY09 to meet these evolving needs. (The table in appendix 4 shows how FORT accomplishments in 2009 relate to specific Science Strategy areas.)

\section{Science Accomplishments}

Highlights of FORT project accomplishments are described below under the USGS science program with which each task is most closely associated, although there is considerable overlap. The work of FORT's five branches (Ecosystem Dynamics, Information Science, Invasive Species Science, Policy Analysis and Science Assistance, and Trust Species and Habitats) often involves major partnerships

\footnotetext{
${ }^{1}$ ASRC Management Services, under contract to the U.S. Geological Survey, Fort Collins Science Center, 2150 Centre Avenue, Building C, Fort Collins, Colo. 80526-8118.
} 
with other agencies, cooperation with other USGS disciplines (Geography, Geology, Geospatial Information, Water Resources), and new thrusts. These are noted using the following symbols:

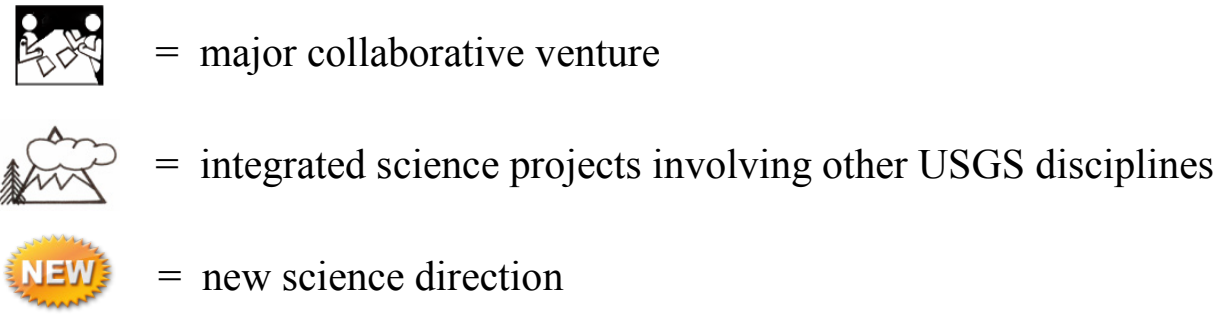

\section{Biological Informatics}

Science activities in this category support the implementation of technologies and tools to integrate, analyze, visualize, and apply biological information to natural resource issues and to provide research that supports the advancement of biological informatics capabilities. Work includes increasing the availability and usefulness of biological data and information and applying standards to enhance its discovery and retrieval.

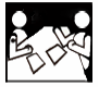

Identifying Gunnison Sage-Grouse Nesting Habitat. Gunnison sage-grouse (Centrocercus minimus) are currently being considered for listing under the Endangered Species Act. In order to make an informed decision concerning that listing, knowledge of the habitat requirements of the species is necessary. The identification of nesting habitat is particularly important because of its impact on recruitment of young. FORT scientists have partnered with National Park Service (NPS) personnel to identify Gunnison sage-grouse nesting habitat in the western portion of Colorado's Gunnison Basin by using advanced empirical modeling techniques. Data inputs for the resulting model were provided by many cooperating agencies including the Bureau of Land Management (BLM), the U.S. Forest Service (USFS), the NPS, and Gunnison County. The resulting model was presented to the Gunnison SageGrouse Working Group, and FORT scientists were subsequently asked by the U.S. Fish and Wildlife Service (USFWS) to apply the model to the entire Gunnison Basin. This information will then be considered in the listing process. The Gunnison Basin in western Colorado is home to about 75 percent of the total population of Gunnison sage-grouse (approximately 2,000 individuals). Maintenance of the Gunnison sage-grouse population in this area is imperative if the species is to persist.

Metadata Development and Quality Control. In order to increase the availability of biological data and information, in FY09 the FORT Metadata Team created metadata for FORT publications and for information and data products at the project and dataset levels. Metadata produced are compliant with the Federal Geographic Data Committee Biological Data Profile (FGDC/BDP) metadata standards and are served on the National Biological Information Infrastructure (NBII) Clearinghouse. The FORT Metadata Team also served as a national contact for metadata submitted to the NBII Principal node, performing quality control steps to ensure that metadata prepared for serving online have appropriate content and meet the syntax rules specified in the FGDC/BDP Content Standards. The FORT Metadata Team created several visualizations of NBII clearinghouse holdings and wrote custom scripts to automate tasks to enhance the quality of served metadata records. 


\section{Enterprise Information}

This work involves creating elements of the USGS Integrated Information Environment.

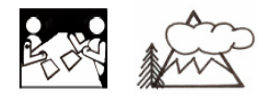

Development of Web Applications for Project and Performance Tracking. To help

FORT partners efficiently track significant amounts of data and meet management objectives, the FORT Web Applications Team builds and deploys project and performance tracking systems. These Web-based applications securely collect information from working teams to help users and management determine whether (1) interim and long-term requirements and criteria are being met, (2) existing protocols are providing appropriate and sufficient information, and (3) data are being collected as specified. The information gained through this process supports team decisionmaking in real time through maps, graphs, charts, and summary reports. Project and performance tracking applications implemented in FY09 include the Radio Asset Inventory System, National Invasive Species Council Tracking System, Human Capital Document Review System, Species-Habitat Requirement Information Management Program, and the Jonah Infill Data Management System (http://www.fort.usgs.gov/JIO).

USGS Network Security. FORT staff continued to serve on the USGS IT Security Operations Team (ITSOT), providing technical assistance and developing anti-malware solutions and processes for the Bureau. Work in FY09 focused on implementing a USGS Centralized Antivirus Solution (designed and developed by the GIO and FORT Computer Operations Team in FY08) that allows centralized malware reporting and control of all USGS systems. FORT staff tested, piloted, and deployed the solution in 2009, which is now being applied to all science centers and field sites across the USGS. In addition to implementing this system, FORT staff assisted the USGS and the DOI in detecting and resolving malware issues (viruses, trojans, and the like), including variants undetectable by many antivirus products.

\footnotetext{
sis and integrate data and ideas across a variety of information systems. The USGS Integrated Information Environment (IIE) helps to address this need. Several converging ideas in the IIE suite of projects have brought about the concept of a "ScienceBase": an integrated database of information from many different data and information sources, such as existing data systems, metadata catalog systems, and new original content. While not a traditional data warehouse, ScienceBase serves some of the same functionality at a high level of detail. In FY09, FORT led the effort to implement the backbone architecture required to support ScienceBase.
}

Integrated Information Environment Application Development and Support. The interdisciplinary nature of natural resources issues requires USGS scientists to be able to communicate

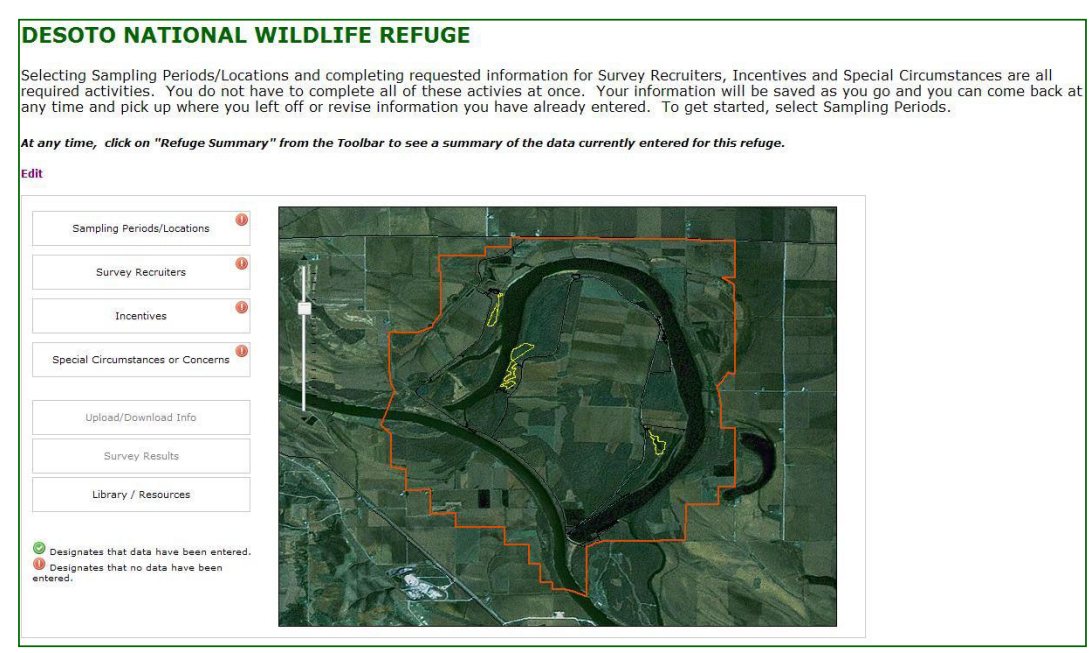

Screen capture from Refuge POC, a Web application utilizing the ScienceBase Footprint Studio to assist FORT social scientists in conducting the National Wildlife Refuge System Visitor Survey. Using this application, the designated Refuge POC (Point of Contact) will identify the survey time frames and locations where collection of visitor contact information will occur. They will also identify surveyors who will collect the visitor contact information and indicate incentives and special concerns. USGS image. 
A core component of the ScienceBase concept is the continual addition of modular applications that can be plugged into many different systems over time. This is based on the concept of an "IIE Toolbox," a set of component features (tools) to help application and Web developers build data and information management systems quickly and consistently across the organization. Some of the tools built by FORT developers in FY09 include ScienceBase Directory Services, ScienceBase Catalog, and ScienceBase Footprint Studio. In addition, FORT added features to core "myUSGS" components of the ScienceBase model, including enterprise authorization, content management, and issue tracking.

\section{Fisheries: Aquatic and Endangered Resources}

Activities related to fish and aquatic resources involve research and technical assistance that promotes an understanding of the relationships among aquatic species and habitats. Such an understanding will help to conserve or restore community structure and function-especially for at-risk species. Products include research and technology tools that support problem solving, decisionmaking, and development and evaluation of adaptive management strategies for restoration and maintenance of aquatic resources.

Research and Design Guidelines for River-Spanning Rock Structures. River-spanning rock structures serve a unique and necessary role in meeting water delivery goals in an ecologically sound manner. Such structures can be used to replace low-head diversion dams, permit fish passage, create habitat diversity, and stabilize stream profiles. A scientific- and mechanistic-based understanding of structure behavior enables managers to make supportable planning and management decisions and adapt to new circumstances. Current design methods primarily rely on individualized professional experience and anecdotal information, with mixed success.

In 2008, FORT scientists began collaborating with Colorado State University and the Bureau of Reclamation (henceforth "Reclamation") on research that incorporates a multifaceted approach. This approach employs field data to identify prototype conditions that provide practical and applied information, laboratory physical modeling to

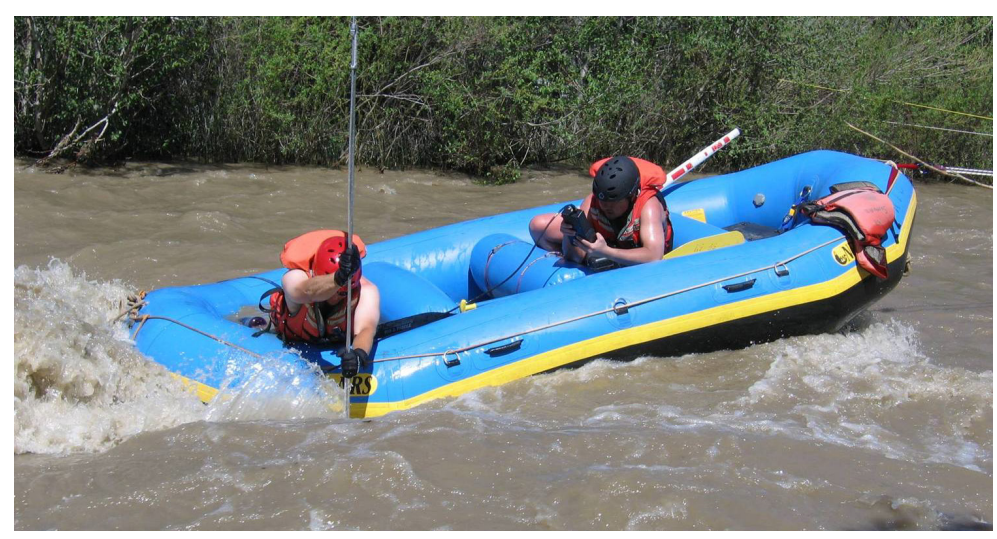

Rio Blanco River in Colorado. Field survey and velocity measurement from a raft at bankfull flow. USGS photo by Chris Holmquist-Johnson.

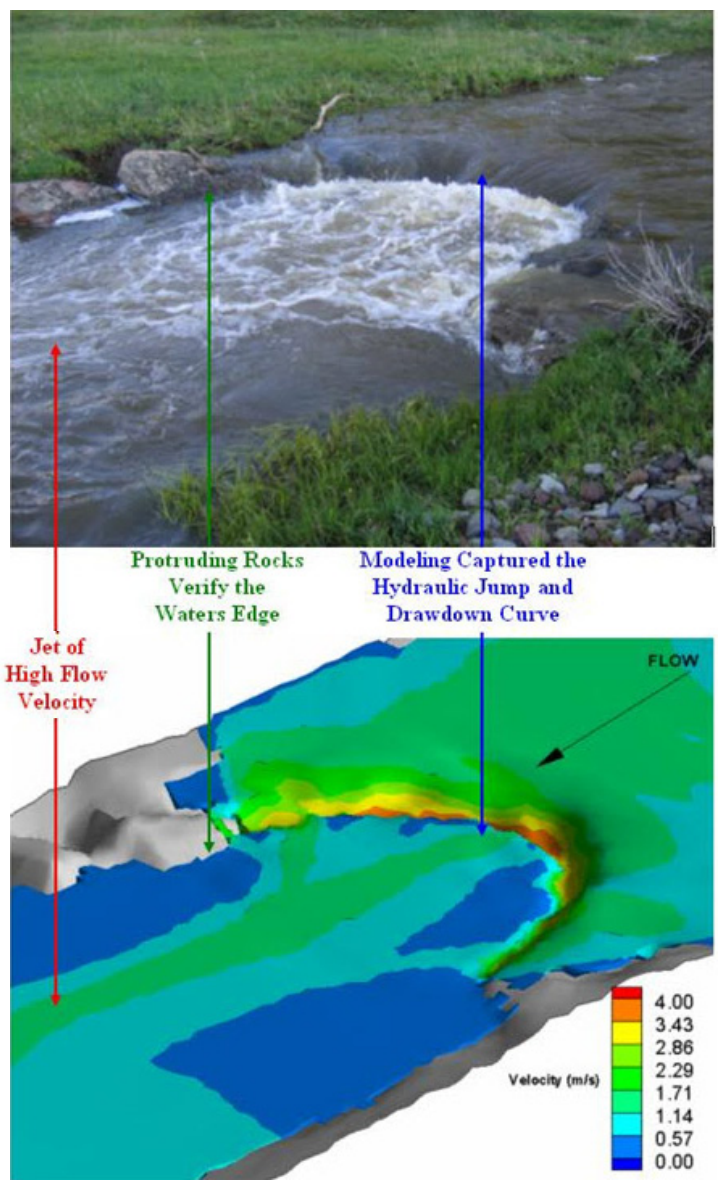

Field photo and illustration comparing field data measurements with results from a 3-dimensional numerical model. USGS images. 
isolate key variables and study individual processes in detail, and computer modeling to develop design tools and predictive capability for analysis and design. In FY09, FORT researchers developed a conceptual model of success, failure, and performance based on field measurements, laboratory tests, and numerical modeling. Work in progress involves developing quantitative design and analysis techniques that will be integrated into a final report on the hydraulics and scour of river-spanning rock structures. This information will offer design considerations to engineers and managers for maximizing the sustainability of the structures.

\section{Application of the Hydroecologi- cal Integrity Assessment Process} for Missouri. FORT scientists and colleagues in the USGS Water Resources Discipline completed an application of the Hydroecological Integrity Assessment Process (HIP) to Missouri streams. The team developed and delivered a customized version of the HIP software to the Missouri Department of Conservation and published a report on the work, "Application of the Hydroecological Integrity Assessment Process for Missouri Streams" (USGS Open-File Report 2009-1138;

http://www.fort.usgs.gov/Products/Publicat ions/pub_abstract.asp? PubID=22681). HIP consists of (1) a regional classification of streams into hydrologic stream types based on flow data from long-term gagingstation records for relatively unmodified streams, (2) an identification of stream-type specific indices that address 11 subcomponents of the flow regime, (3) an ability to establish environmental flow standards, (4) an evaluation of hydrologic alteration, and (5) a capacity to conduct alternative analyses.

The process starts with the identification of a hydrologic baseline (reference condition) for selected locations, then uses

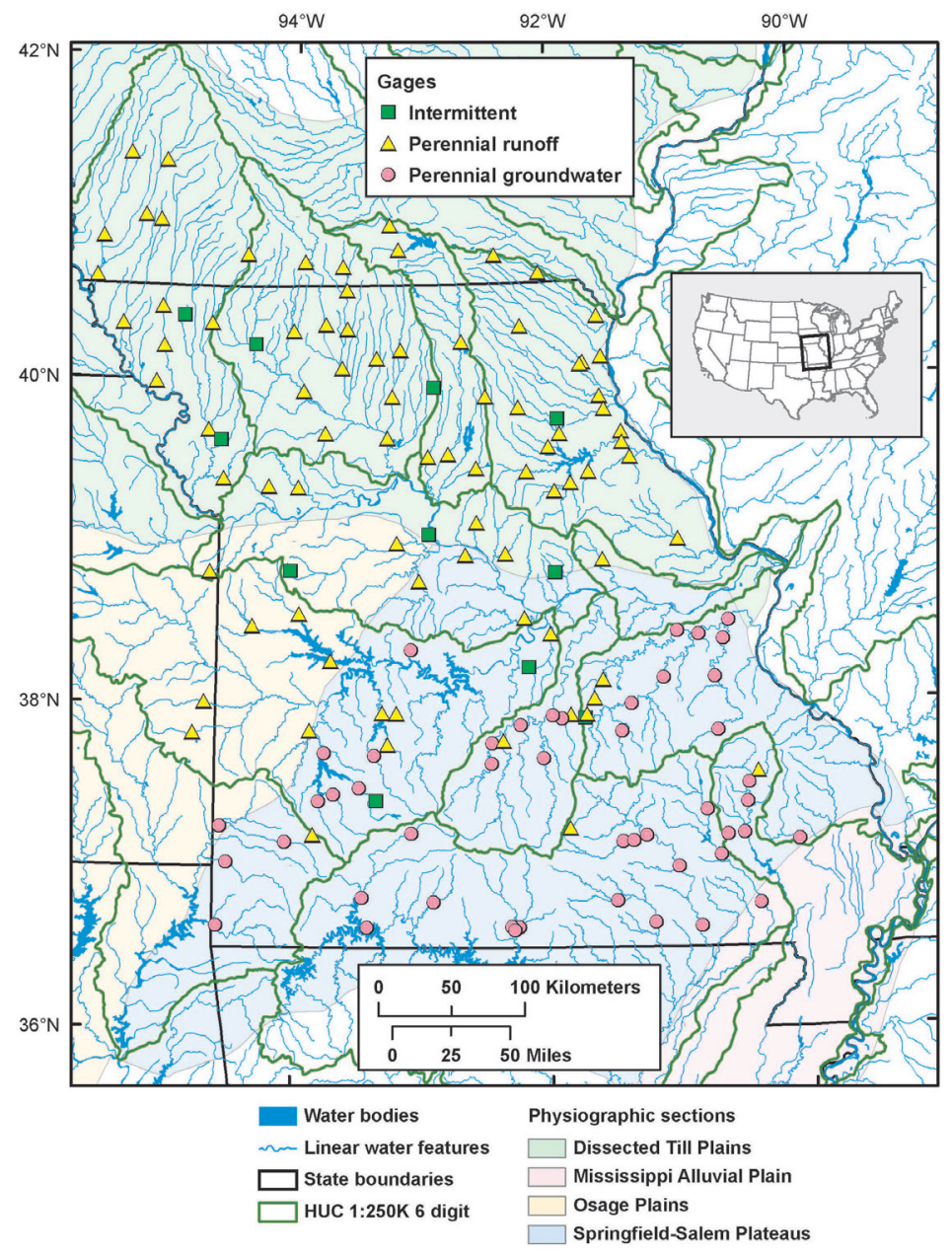

Location of physiographic sections and streamflow sites used to classify the three primary stream types in Missouri. Each symbol represents a USGS streamflow-gaging station and is color coded to indicate a primary stream type. USGS image.

flow data from a stream-gage network, and proceeds to classify streams into hydrologic stream types.

Concurrently, the analysis identifies a set of non-redundant and ecologically relevant hydrologic indices for 11 subcomponents of flow for each stream type. To further enhance the process, regional hydrologic models for synthesizing flow conditions across a region and the development of flow-ecology response relations for each stream type can be added. In FY09, FORT contributed to the statistical analyses of the flow data for classification of streams, statistical summaries, and discussions in the Open-File Report (2009-1138, http://www.fort.usgs.gov/Products/Publications/pub_abstract.asp?PubID=22681) on strengths and limitations of the method. 
Role of SALMOD in the Klamath River Secretarial Determination Process. In 2009, an Agreement in Principle was signed by the Department of the Interior, the States of California and Oregon, and PacifiCorp, Inc., to remove four hydropower dams located in the upper Klamath River Basin in California and Oregon. The upcoming Secretarial Decision (SD) to either remove or retain the hydropower dams on the Klamath must be supported by objective, quantifiable evidence that this action will either benefit or not benefit anadromous fish stocks. FORT has developed a fish production model (SALMOD) that has been applied to resource management issues in both the Klamath and Trinity River basins. The DOI has chosen SALMOD to represent the freshwater-life-cycle component of a fulllife-cycle model being developed by the National Oceanic and Atmospheric Administration (NOAA) Fisheries Office in Santa Cruz, Calif., for the SD. FORT and NOAA have an interagency agreement to work together to develop the full-life-cycle model, wherein FORT is providing the freshwater component and NOAA is providing the ocean component for fall Chinook salmon. Additionally, the USFWS office in Arcata, Calif.; Texas State University; Reclamation; and tribal governments are all working together to provide data sets, fish-disease factors, future hydrology sequences, and companion air temperature and precipitation forecasts that will provide the basis for model simulations of future climate conditions on fish production. These model simulations will be used to estimate levels of fish production in the Klamath River Basin, with and without the Klamath River dams.

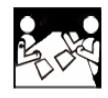

Environmental Flow Studies to Establish a Water Right Benefit. The use of water for environmental purposes within streams has gained increasing visibility. The state of Arizona allows water-right applications for maintaining instream flow. Under an Interagency Agreement with the U.S. Forest Service, FORT designed a study to quantify the benefit of providing an instream water right in Cherry Creek, which runs through the Tonto National Forest in central Arizona. Scientists investigated habitat response to streamflow for native and introduced fish species. Using these data, investigators provided a decision-support system that quantifies the long-term habitat effects of (1) reduced streamflow caused by withdrawing water from the stream and (2) constraining such withdrawals by a water right. The Arizona Department of Game and Fish also cooperated in the study. Specific FY09 accomplishments include finishing the analysis and writing the report (Open-File Report 2009-1272, http://www.fort.usgs.gov/products/publications/pub_abstract.asp?PubID=22858), which will be used in a water rights case in Arizona. As with all legal cases, there is potential to establish a precedent.

\section{Invasive Species}

Research on invasive species involves (1) collecting, synthesizing, and providing information on invasive species; (2) early detection and rapid assessment of new invaders or incipient populations; (3) monitoring and forecasting changes in populations and distributions of established invaders; (4) developing and testing prevention, control, and management strategies; and (5) determining invasive species' impacts and habitat susceptibility to invasion.

\footnotetext{
Biological Invasion of Riparian Ecosystems: Saltcedar and Russian Olive State-ofand the-Science. The Salt Cedar and Russian Olive Control Demonstration Act of 2006
} (Public Law 109-320) directs the DOI to submit a report to Congress that includes an assessment of several issues surrounding these two non-native trees, now dominant components of the vegetation along many rivers in the western United States. This report, "Saltcedar and Russian Olive Control Demonstration Act Science Assessment," was developed throughout FY09 and published in 2010 as a USGS Scientific Investigations Report 2009-5247 (http://www.fort.usgs.gov/Products/Publications/ pub_abstract.asp? PubID=22895). The report was produced through a collaborative effort led by the 
USGS and Reclamation, with contributions from the U.S. Department of Agriculture (USDA), university researchers, and others. FORT scientists contributed in a lead editorial role and co-authored 5 of 8 chapters. The document synthesizes the state of the science and key research needs on the following topics related to management of saltcedar (Tamarix spp.) and Russian olive (Elaeagnus angustifolia) in the western United States: their distribution and abundance (extent), the potential for water savings associated with controlling these species, considerations related to wildlife use of saltcedar and Russian olive habitat and restored habitats, methods of control and removal, possible utilization of dead biomass following control and removal, and approaches and challenges associated

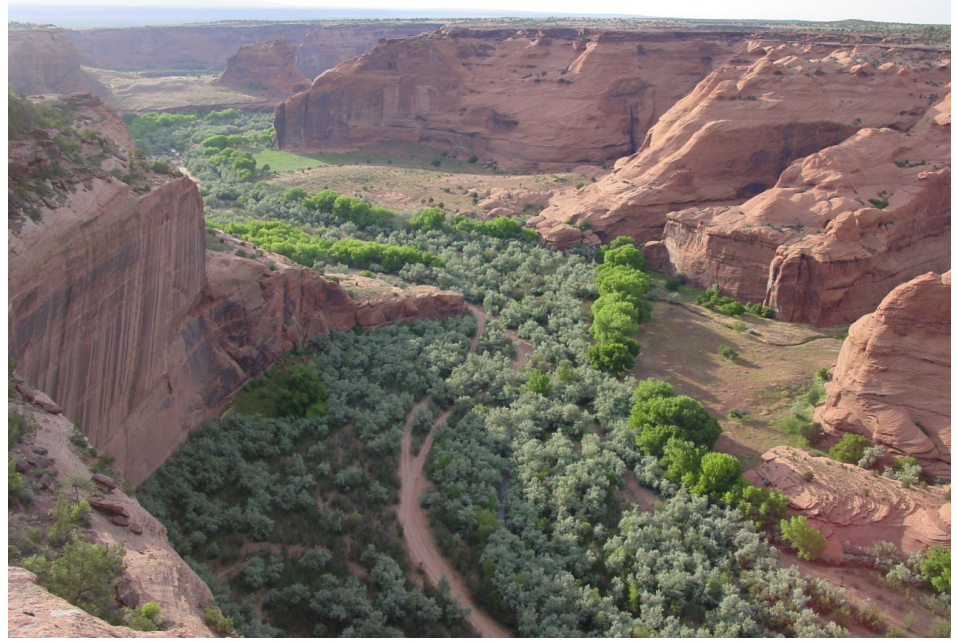

Photo of Chinle Wash in Canyon de Chelly National Monument, Arizona, 2005. Nonnative, invasive Russian olive trees (gray-green foliage) are interspersed with invasive saltcedar (dark green shrubs in the shaded area) on the floodplain. Bands of native Fremont cottonwood (bright green trees) grow on the outer margins. Photo by Lindsay Reynolds, Colorado State University. Used with permission. with site revegetation or restoration. A concluding chapter discusses possible long-term management strategies, potentially useful field-demonstration projects, and a planning process for on-the-ground projects involving removal of saltcedar and Russian olive. The report is expected to be used by a broad range of scientists and policymakers as further plans are developed for research, monitoring, and management of these ubiquitous invasive plants.

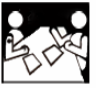

Resource for Advanced Modeling: Extending Research on Invasive Species Habitat Modeling and Expanding Our Partnerships. The Resource for Advanced Modeling, or "RAM," was renamed, renovated, and updated in FY09, replacing the former Advanced Invasive Species Modeling Room. Use of RAM in the past year has added significantly to developing new partnerships involving a wider range of taxa, including rare native species. In FY09, the RAM team made extensive progress in

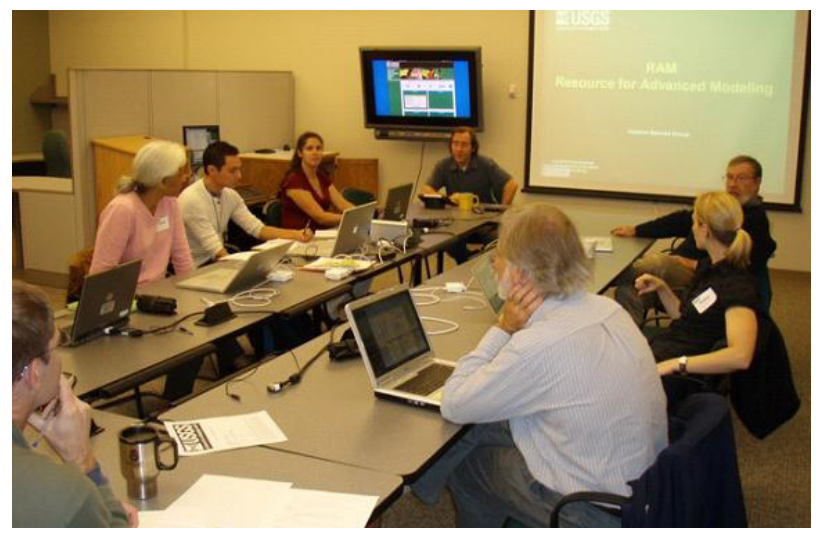

USGS and NASA researchers used the Resource for Advanced Modeling (RAM) to develop preliminary ecological habitat models for the Africanized honey bee in the United States in the inaugural topical meeting in the RAM. USGS photo.
FORT's partnership with NASA in modeling current and potential distribution of the Africanized honey bee, especially in moving from county-based models to a national analysis. Through collaboration with the National Park Service, FORT developed "ensemble models" wherein grouping model outputs from several models was found to work better than individual models alone. Finally, in collaboration with the EPA, we modeled the distribution of Didymosphenia geminata. This diatom is spreading to streams and lakes where it has not previously occurred, causing "nuisance blooms" that cover streambeds. This work increased our understanding of modeling aquatic organisms that are important to water quality and fish habitat. 
Advanced Research on Invasive Species Habitat Modeling. The "Advanced Modeling" research and development component of the Invasive Species Science Branch focused on making advances in five major areas. Much of this effort was accomplished through collaboration with Colorado State University. In FY09, we tested several models using small sample sizes, which are ideal for threatened and endangered species. Our studies produced accurate models for an endangered tree species (Canacomyrica monticola) in New Caledonia, the Yosemite toad (Bufo canorus) in California, and the endemic mountain nyala (Tragelaphus buxtoni) in Ethiopia. We also continued expanding our abilities to manage and incorporate various types of remotely sensed data (time series/phenology data in particular); the resulting data and techniques point the way to future predictors of habitat suitability for our species-distribution modeling activities. We added near-term climate change scenarios to improve ecological forecasting capabilities and made extensive progress in assisting the Global Invasive Species Information Network (see http://www.gisinetwork.org/). Lastly, we are improving techniques for gathering and using data from citizen scientists (see www.citsci.org).

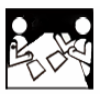

\section{Control and Prevention of the} Invasive Brown Treesnake. The Brown Treesnake (Boiga irregularis) is a highly destructive species that has extirpated many native bird species on Guam, as well as bats and lizards. Visual searching is one technique currently used to detect and control Brown Treesnakes, especially incipient populations. The cost of an eradication program depends upon the least capturable individual. Heterogeneity (analysis of capture variability) in visual detection probabilities sets the cost for control efforts, particularly control programs directed at eradicating an incipient or nearly extirpated population. In FY09, we com-

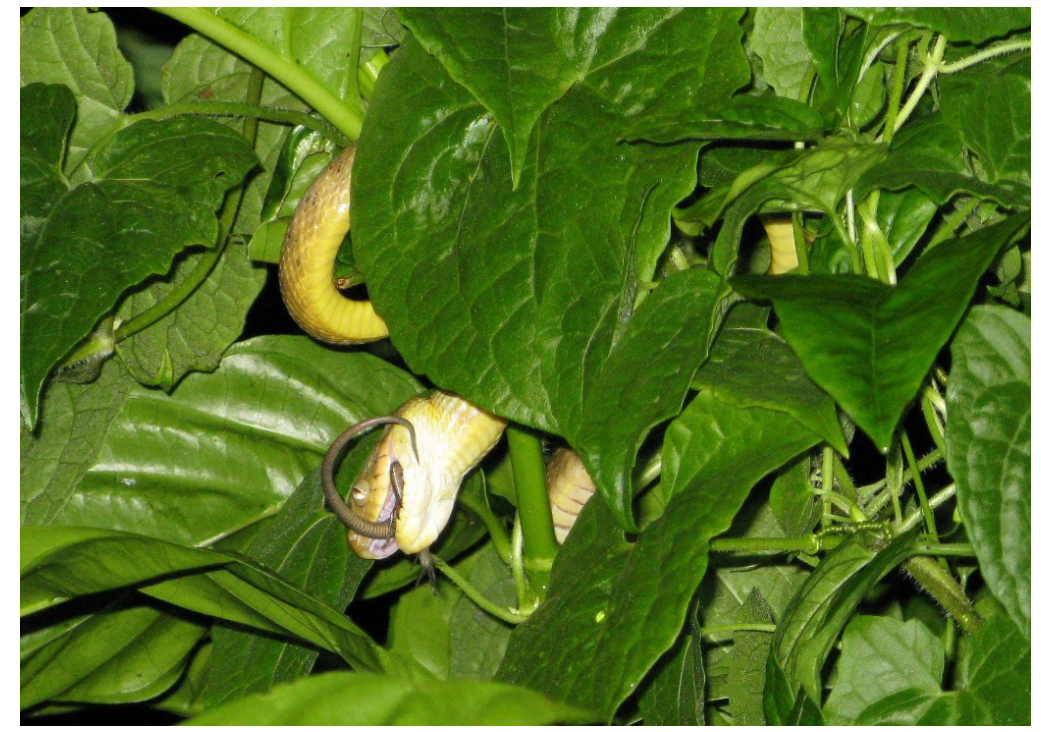

Invasive brown treesnake consuming a gecko on Guam. USGS photo by Robert Reed. pleted several studies analyzing visual detection probability. Biologists also conducted two trials on a closed population of Brown Treesnakes on Guam to determine absolute and relative effectiveness of bait tubes on all sizes of snakes, including one trial in a prey-dense environment, as might be encountered in an accidental introduction. Results published by FORT in FY09 on food preferences in juvenile Brown Treesnakes led to further research in scent attractants, which is ongoing. FORT scientists are analyzing trial data to determine the effectiveness of detector dogs in finding Brown Treesnakes in low-canopy forest. Biologists assisted the USFWS and the Department of Defense (DOD) in forming barrier-construction plans around the Habitat Management Unit, a 66-hectare area on Guam. Cooperators include the DOI Office of Insular Affairs, USFWS, DOD, Guam Division of Aquatic and Wildlife Resources, USDA Wildlife Services, Hawaii Department of Agriculture, Hawaii Department of Forestry and Wildlife, and Commonwealth of the Northern Mariana Islands (CNMI) Department of Fish and Wildlife. 

strictor snakes have become established in the greater Everglades ecosystem and are expanding their range in southern Florida. These giant snakes (up to 20 feet and 250 pounds) are efficient predators of warm-blooded species ranging from wrens to deer, and represent a novel threat to which native species are poorly adapted. In 2006, FORT scientists with expertise in control of invasive reptiles were asked by cooperating agencies to initiate a major new science direction focused on developing techniques to detect, capture, and control populations of giant constricting snakes in Florida and elsewhere (see http://www.fort.usgs.gov/FLConstrictors/). In FY09, development of capture tools contin-

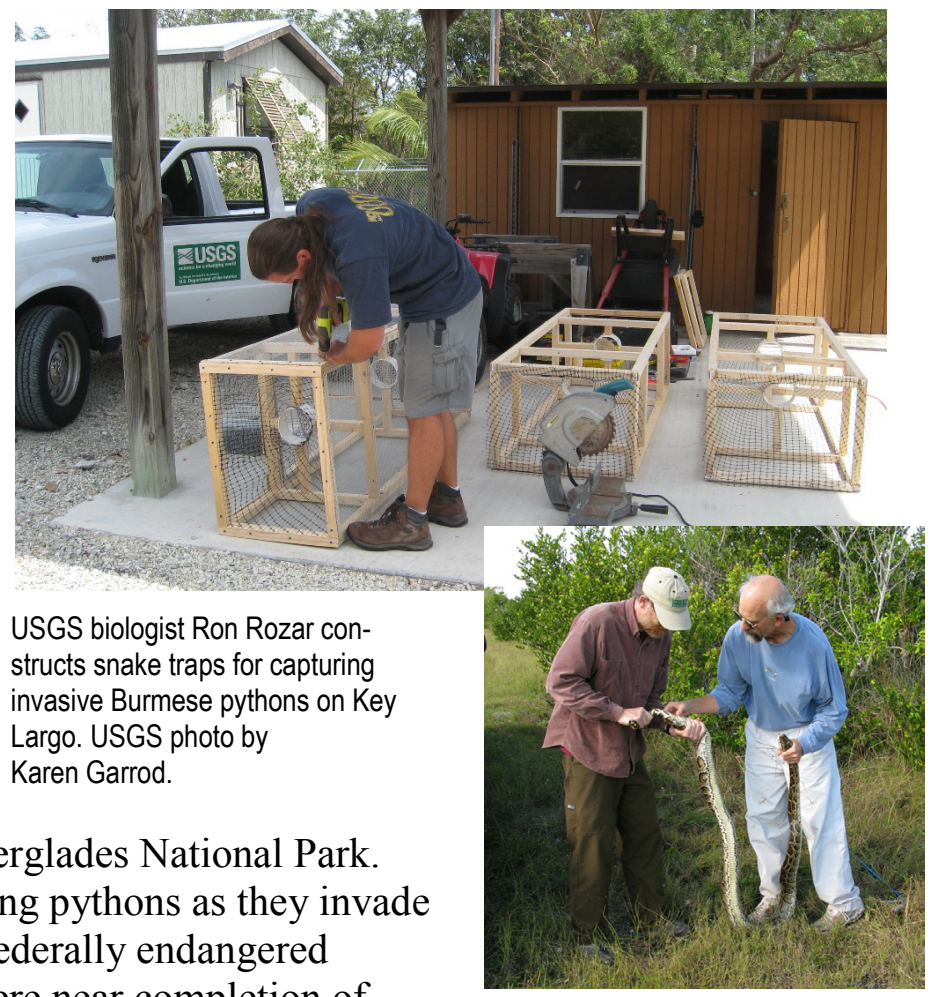

USGS zoologist Gordon Rodda and NPS biologist Skip Snow examine a captured Burmese python along U.S. 41 in the Everglades. USGS photo by Robert Reed. Constrictor" (Open-File Report 2009-1202 http://www.fort.usgs.gov/ products/publications/pub_abstract.asp?PubID $=22691$; released and presented to Congressional staff in FY2010) for use in formulating policy to prevent further invasions. Cooperating agencies include the Endangered Species and National Wildlife Refuges branches of the USFWS, NPS, South Florida Water Management District, Florida Department of Environmental Protection, University of Florida, and Florida Wildlife Commission.

Control of Invasive Watersnakes in California. Invasive watersnakes have become established in at least four locations in California. Without interdiction, these species will likely expand their range and colonize other regions in the western United States, as they are dietary generalists and prefer temperate climates. These invasive watersnakes may compete with native reptilesincluding those listed as threatened or endangered under the Endangered Species Act (ESA) - for available prey, transfer parasites to native herpetological populations, and consume ESA-listed amphibians and fishes.

FORT scientists with expertise in controlling invasive reptiles were asked by cooperating agencies to initiate a new science direction focused on developing techniques to detect, capture, and control populations of invasive watersnakes in California and elsewhere. In FY09, FORT scientists began developing capture tools in areas with high invasive watersnake densities in and around Lake Machado, Calif., a public lake in Harbor City in northwestern Los Angeles County. Results will be applied to detecting and capturing watersnakes in support of conservation efforts for federally endangered taxa. Results will also inform agency managers of additional populations of introduced watersnakes in California (at least three other populations, each representing a different species, are established in the state). 
Cooperators include the Non-native Invasive Species and Ecological Services branches of the USFWS, the California Fish and Game Department, the University of Toronto, the Los Angeles County Parks and Recreation Department, ECORP Consulting, and the Environmental Planning Group.

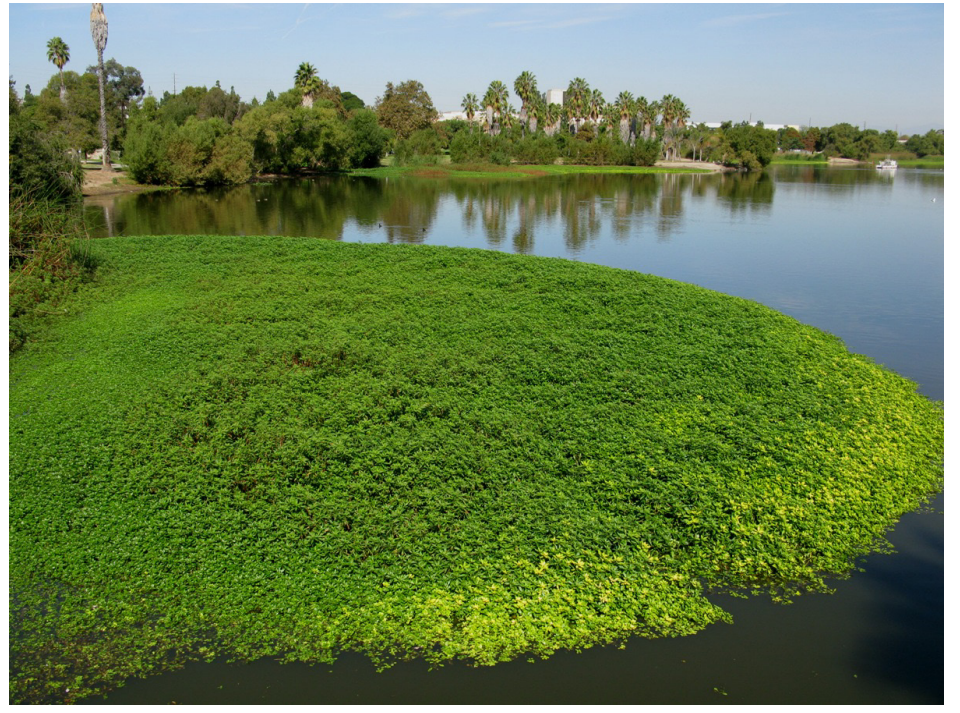

Machado Lake, site of water snake invasion and USGS study in southern California. USGS photo by Robert Reed.

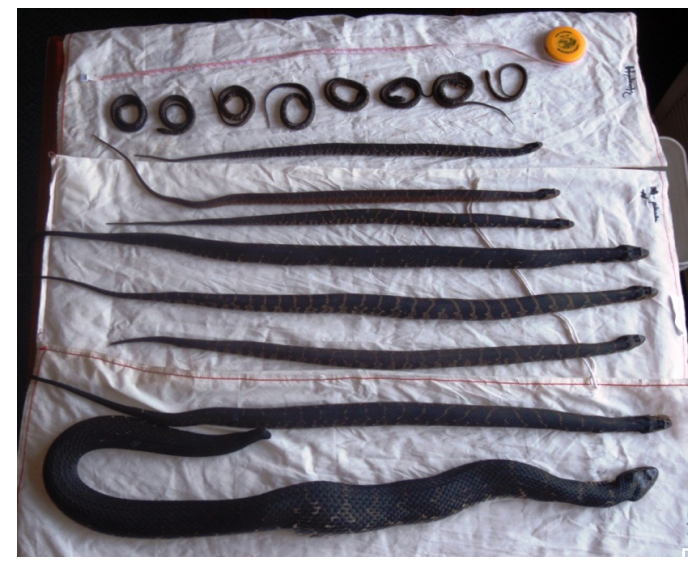

One day's take of invasive water snakes on Machado Lake in southern California. USGS photo by Robert Reed.

\section{Status and Trends of Biological Resources}

Status and trends research identifies ongoing or impending changes to species, habitats, and ecosystems. Key goals include developing and evaluating inventory and monitoring protocols, analytic tools, and other technologies to measure biological status and trends; collecting, archiving, and sharing critical, high-quality monitoring data in cooperation with partners; and providing analyses and reports that synthesize this information for the scientific community, resource managers, policymakers, and the public.

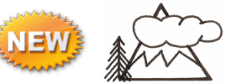

The John Wesley Powell Center for Earth Systems Science Analysis and Synthesis. The John Wesley Powell Center for Earth System Analysis and Synthesis at the Fort Collins Science Center was inaugurated in FY09 (see http:/powellcenter.usgs.gov). The Powell Center facilitates the increasingly important task of synthesizing biologic, hydrologic, geologic, geographic, and economic knowledge in order to address complex environmental and societal problems. Additional benefits for the USGS are the opportunity to bring together vast USGS databases to create new knowledge and tools and the potential for scientist-initiated interdisciplinary activities. The unique and stimulating environment at FORT, with its exceptional technical support and facilities, enables scientists to advance the state of knowledge through collaborative and interdisciplinary investigation. Powell Center Working Groups organize and synthesize scientific information, thereby empowering researchers, resource managers, and policymakers to address important earth system science issues. The first set of Working Group proposals were submitted in 2009. Three proposals were selected for support by a world-class Scientific Advisory Board. Working Groups will begin meeting in 2010.

Integration of USGS and University Natural History Collections. Curatorial staff at FORT are nearing the final phases of integrating significant and valuable scientific collections with those of the University of New Mexico's Museum of Southwestern Biology (MSB; http://www.msb.unm.edu/) in 
Albuquerque, N. Mex. In FY09, FORT museum scientists completed physical integration of over 12,000 specimens of amphibians and reptiles and 265,000 fishes into the holdings of the MSB. This Federal collection of vertebrates ( $h t t p: / / w w w . m s b . u n m . e d u / U S G S / i n d e x . h t m l)$ has served as a repository for specimens taken in support of Federal research in the West for nearly 100 years. Much of this research has documented the taxonomy, distribution, and abundance of vertebrates on Federal land, including threatened and endangered species. These studies continue today.

By combining Federal and University specimens and their associated data in one location, specimen data can be quickly accessed, downloaded, mapped, and linked to publications and other external resources on the Web. The enhanced collections will likely find increased use by the scientific community_including Federal agencies such as the NPS, the USFWS, and the USFS, from whose lands specimens were collected. Providing access to these irreplaceable collections will benefit long-term USGS research strategies focused on climate change, biodiversity, predicting and understanding ecosystem change, and evaluating the impacts of hazards and resource use on the environment and human health.

\section{NEII) Using LiDAR to Measure Sagebrush Structure and Predict Pygmy Rabbit Site Occupancy.}

Energy development, such as southwestern Wyoming's intensive development of fossil fuel and wind energy, and other land uses are reducing and degrading sagebrush (Artemisia spp.) habitats throughout their range. Recent studies have successfully used LiDAR to estimate shrub height and density in sagebrush systems, demonstrating the potential for LiDAR to map attributes of sagebrush vegetative structure over broad areas. This input will likely increase our understanding of habitat requirements of key sagebrush-obligate wildlife such as the pygmy rabbit (Brachylagus idahoensis), a Federal candidate species for

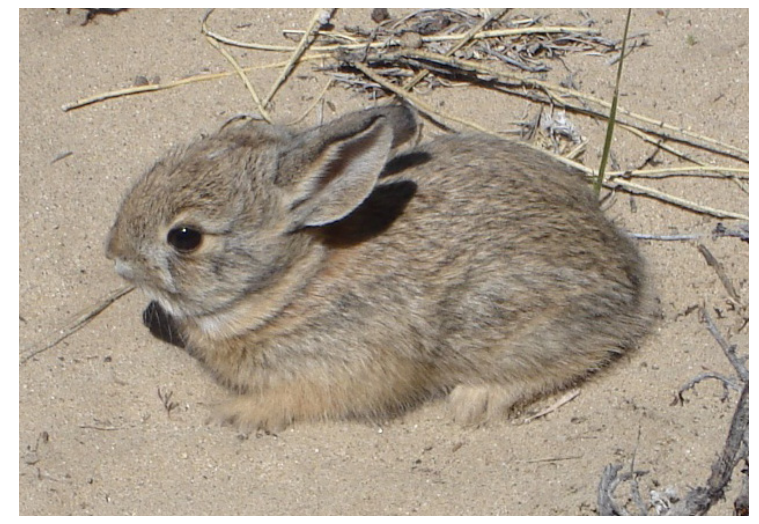

Pygmy rabbit. USGS photo. listing under the Endangered Species Act. In October 2009, FORT scientists collected LiDAR data in a 500-square-mile area of sagebrush in southwest Wyoming. In 2010, scientists will collect ground-based vegetation measurements and conduct pygmy rabbit site-occupancy surveys throughout the acquisition area to (1) quantify how accurately LiDAR data estimates sagebrush vegetative structure and (2) incorporate LiDAR data into an improved habitat model for the pygmy rabbit. Information on the ability of LiDAR to estimate sagebrush vegetation will be shared with all partner agencies in the Wyoming Landscape Conservation Initiative (http://www.wlci.gov/). The improved pygmy rabbit habitat model will enable resource managers to make more informed conservation decisions for this species in the face of continued landscape-scale development.

Mapping National Historic Trails. As part of its National Trails System, the National Park Service has responsibility for managing national historic trails, routes of travel that are of significance to the entire Nation. The National Trails System (NTS) maintains a geographic information system (GIS) database of historic resources for the Oregon, California, Mormon Pioneer, and Pony Express National Historic Trails. FORT is working with the NTS office to more accurately document and map the historical trail corridor in Oregon and Wyoming. This project is referencing (1) scanned paper maps that contain notes and approximate trail locations and (2) 1970s panchromatic aerial photography in a geographic information system (GIS) to more accurately delineate the national historic trails. FORT 
specialists will also work with the staff of the National Archives to search for historical aerial photography that will be used to map additional portions of the NTS.

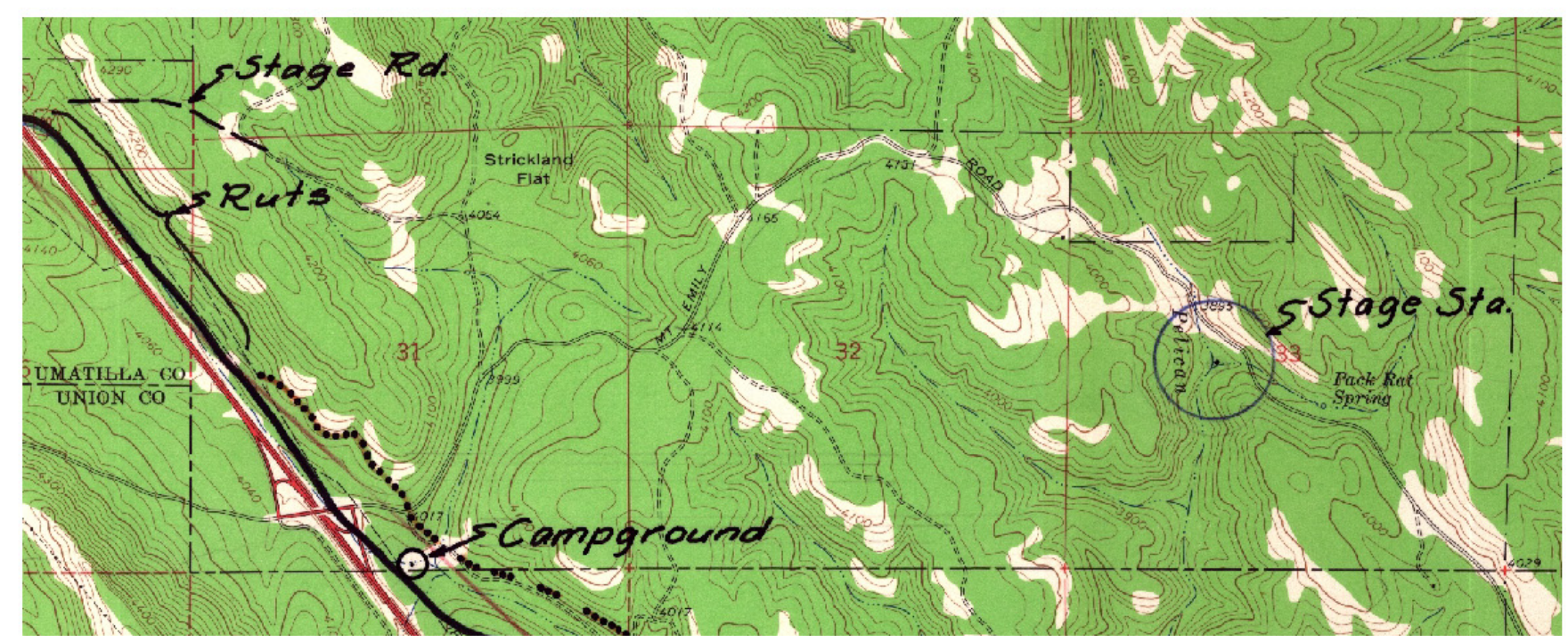

A section of the Huron, Ore., quadrangle, dated 1964, showing confirmed sections of the Historic Oregon Trail (dotted lines) and general locations of the trail (solid line) mapped by the Oregon State Highway Department. The locations of a stage station and a portion of the stage road are also shown. FORT is referencing paper maps and aerial photographs to create a GIS database of the Oregon Trail. National Park Service image.

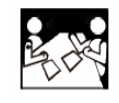

Understanding Conflicts over Science in Bureau of Reclamation Decision Processes. Managers and scientists in Reclamation sometimes find that their decision processes are complicated by conflicts over science. The problem occurs when those involved in developing scientific studies, or those who must use results of those studies for a management decision, disagree over some aspect of the science. Social scientists at FORT are working with Reclamation to learn more about the nature, scope, and resolution of these conflicts. In fiscal years 2008 and 2009, investigators summarized the results of a small survey and workshop focused on this issue. Based on the findings, FORT developed a literature review on methods to resolve conflicts over science. They also developed an online survey that they will administer to approximately 1,500 Reclamation scientists and managers in FY10. Results of these studies will help Reclamation understand the factors that drive these conflicts, approaches that have been used to address the conflicts, and the perceived usefulness of these approaches. The long-term goal is to help Reclamation and others understand and apply the tools and approaches best suited for addressing specific types of conflicts.

\footnotetext{
sins Survey of Moderate Resolution Imagery. Understanding the societal benefits of moderateresolution satellite imagery, such as Landsat, is essential as future land imaging initiatives move forward. The current Landsat satellites provide high-quality, multi-spectral, moderate-resolution imagery of urban, rural, and remote lands for all areas of the world. The utility of this imagery in global climate research, agricultural forecasting, and environmental management is documented. However, there is little understanding of how American industry, nonprofit organizations, and Tribal, State, and local governments use and value the availability of Federally sponsored, moderate-resolution land imaging in decisionmaking.

In FY09, FORT social scientists completed an extensive survey of the uses and benefits of moderate-resolution land imagery (http://www.fort.usgs.gov/News/news_story.asp? WebID=090911). Over
} 
2,500 of almost 5,000 identified users participated in the survey, resulting in a 53 percent response rate. Results will be provided in FY10 to the USGS Land Remote Sensing Program (initiators of the study), the Western Geographic Science Center (collaborators on the study), the EROS Data Center (imagery providers), and other imagery providers and users. These results will be used to inform delivery of the products and services related to this imagery and to understand how and why this imagery is important to users in natural resource decisionmaking.
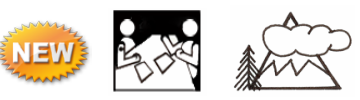

\section{Socioeconomic Considerations for National Wildlife Refuge Management}

and Planning. National wildlife refuge (NWR) managers and planners need clear and objective guidance on the use of socioeconomic information in their resource and visitor services management and planning. Refuges are required by law to develop comprehensive conservation plans. These plans generally must contain an analysis of the particular refuge's social and economic conditions and also evaluate the social and economic effects of likely management scenarios. Moreover, social and economic assessments must be included in the plans in such a way that understanding these factors aids planning decisions and helps guide management actions.

Social scientists and economists at FORT have worked with the USFWS National Wildlife Refuge System (NWRS) to provide social and economic assessments in support of their long-term planning. Research in FY09 involved regional economic impact analyses of current and proposed management activities for four refuges: Canaan Valley NWR, Charles M. Russell NWR, Prime Hook NWR, and Patuxent NWR. Additionally, FORT initiated a National Wildlife Refuge Visitor Survey program. The survey will be given in FY10 to visitors to 52 refuges across the NWRS. (Researchers have already identified the participating refuges and determined the sampling protocol.) This survey will provide valuable baseline information on visitor experience and perceptions related to services, activities, and facilities; visitor spending in the local community related to Refuge visits; visitor understanding of the Refuge mission; and visitor understanding of climate change in a Refuge-specific context.

\section{Terrestrial, Freshwater, and Marine Ecosystems}

Ecosystem investigations aim to quantify and understand factors that influence variation in key ecosystem components over time and space. Emphasis is on developing indices of ecosystem sensitivity to environmental change and vulnerability to potential stressors, as well as producing tools to predict ecosystem responses to change.

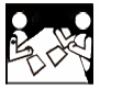

The Western Mountain Initiative. During FY09, FORT scientists and colleagues involved in the Western Mountain Initiative (WMI:

http://www.fort.usgs.gov/products/publications/pub_abstract.asp?PubID=22266) have documented chronic and unexpected climate change effects and have developed guidelines for natural resource management and adaptation to climate change in mountain ecosystems. Evidence of climate-induced background tree mortality at many scales was reported from WMI research and is a good example of multi-factor "stress complexes" that combine to influence ecosystems. The first global assessment of recent tree mortality associated with drought and heat stress was accompanied by a longitudinal study of tree mortality in the western United States. The results of this study were presented in several major publications. An increase in background mortality rates in recent decades is pervasive across elevations, tree sizes, dominant species, and fire history. WMI researchers documented the effects of fire-related stress complexes throughout western forests and the widespread, beetle-caused mortality of whitebark pine in the Greater Yellowstone Ecosystem. 
The continued rapid decline of mountain glaciers and rock glaciers coupled with warming, another stress complex, has led to an unexpected and strong increase in headwater nitrate concentrations. This exacerbates an already significant change in high-elevation lake stoichiometry from atmospheric nitrogen deposition (with impacts up the food chain). All of the issues above pose serious concerns for natural resource managers. The WMI continues to work closely with managers in science-management partnerships to share case studies of adaptation in the western United States and develop long-term, crossboundary strategies.

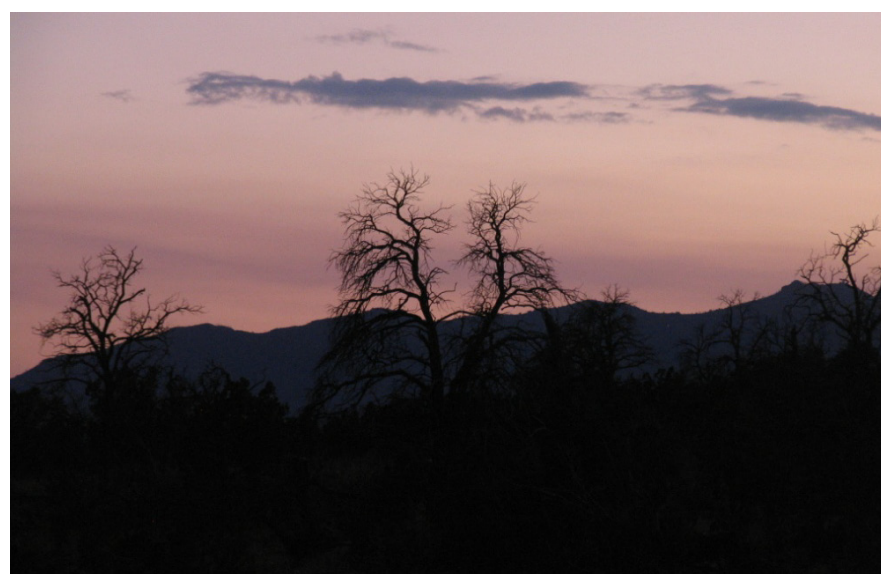

Dead piñon pine trees are evidence of drought- and climate-induced forest dieback in the Jemez Mountains near Los Alamos, N.M. USGS photo by Craig D. Allen.

Sagebrush Ecosystems: Habitat Mapping, Invasive Plants, and Grazing Regimes. Concern for the conservation of sagebrush habitats and associated wildlife is increasing as widespread alteration of these landscapes continues. Although some level of disturbance (for example, wildfire or light to moderate grazing) often benefits these systems, intense and/or frequent disturbances to vegetation and surface soils push community and ecosystem processes into "response and recovery" modes by damaging, reducing, or eliminating local seed bank or perennial plant structures. These alterations have important implications for the quality of both livestock and wildlife habitat.

A multidisciplinary combination of USGS researchers from FORT, the Forest and Rangeland Ecosystem Science Center, the EROS Data Center, and other partners are working to understand the implications of direct and indirect impacts of land-use patterns on ecosystem functions and habitat quality. This research team has accumulated data on the distribution of vegetation and habitats, grazing practices, human land-use patterns, and a host of related environmental patterns. These data are used in analyses that will help public and private land managers conserve, manage, and restore habitats more effectively. Specific FY09 accomplishments include:

- documenting the distribution of invasive plants at more than 100 sites across multi-million-acre regions (completing a 2-year, 200-site effort across southwestern Wyoming);

- completing preliminary analyses of these data, including (1) documenting relationships among invasive plant species as well as among land-use features and (2) interpreting the habitat mapping data through analyses and applications;

- assessing and accumulating data from range-management records (primarily from BLM) from across the western United States that document all available grazing information, including stocking rates and observed range conditions;

- creating a topologically correct spatial dataset of grazing allotment and associated livestock use data; these data will be used, along with other products, to regionally assess the condition of sagebrush ecosystems and habitats; and

- submitting a manuscript for peer review and publication that documents the sagebrush mapping process and results. 


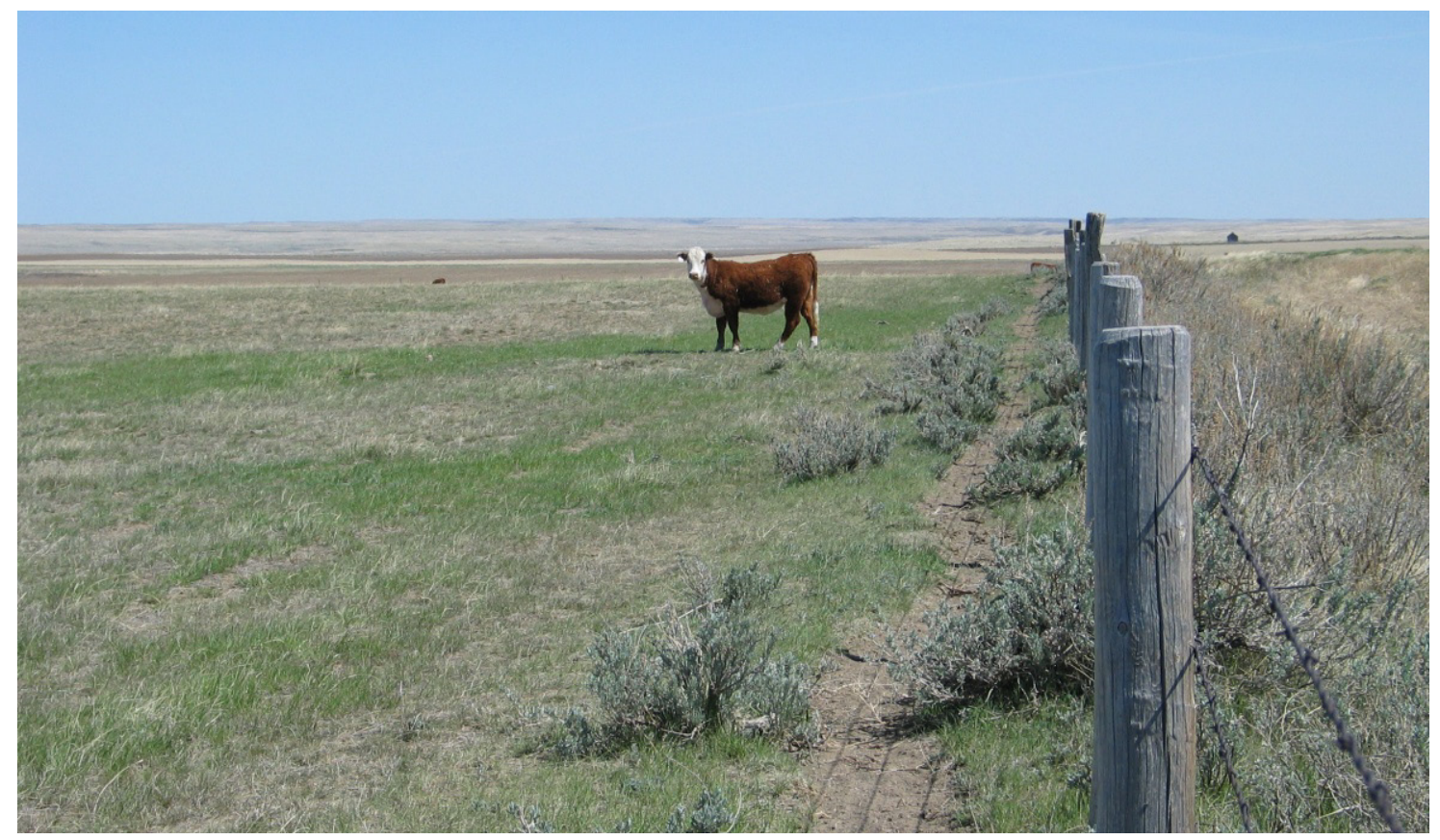

Grazing is one of many elements considered in evaluating the cumulative effects of land-use activities and patterns on sagesteppe systems. Photo by Cameron Aldridge, USGS/Colorado State University.

\section{Wildlife and Terrestrial Resources}

Science conducted in this area provides a foundation for the conservation of terrestrial plants, wildlife, and habitats by developing the basic biological information that partners need to formulate adaptive management strategies. This work seeks to identify factors that contribute to or limit conservation and recovery efforts for species-at-risk and to provide tools and techniques-such as predictive models, decision-support systems, and expert systems - for science-based management of wildlife populations and their habitats. Further, this research aims to address emerging and future issues of importance to our partners by building additional capabilities, expertise, and capacity.

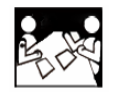

\section{Science for Managing America's}

Wild Horses and Burros. Approximately 37,000 wild horses (Equus caballus) roam 32 million acres of public lands in the West. These horse populations present management challenges that range from the effects of rapid population growth on habitat to ensuring healthy populations for the future. FORT scientists are collaborating with Colorado State University and the BLM in (1) developing population estimation techniques (http://www.fort.usgs.gov/WildHorsePopulations/ Counting.asp) to help managers better assess population levels, and (2) investigating fertility

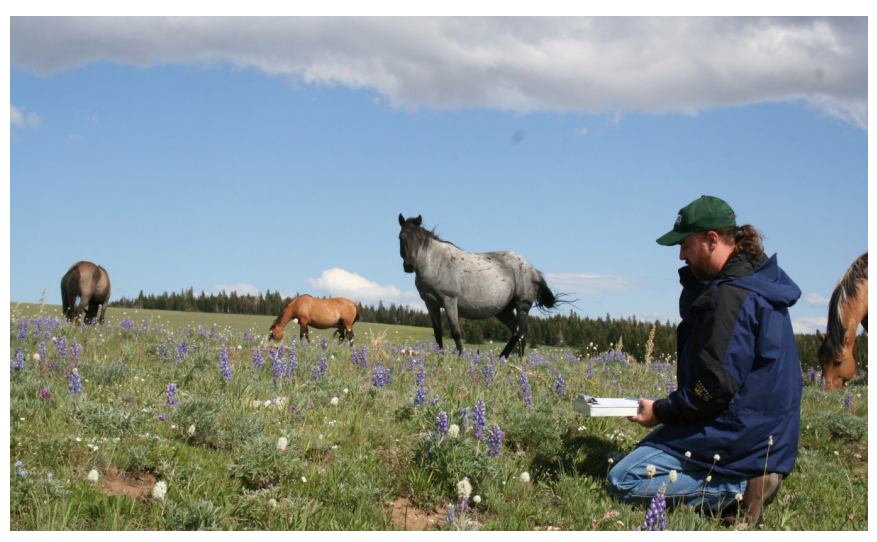

USGS wildlife biologist Jason Ransom conducts fieldwork at the Pryor Mountain Wild Horse Range. USGS photo. 
control (http://www.fort.usgs.gov/WildHorsePopulations/Contraception.asp) to slow population growth rates of wild horses. In FY09, FORT scientists finalized a successful technique for estimating wild horse populations that inhabit areas with forest and complex terrain. The process involves combining a photographic mark-resight technique with sightability bias correction models. Additional tests were also completed in 2009 on a simultaneous double-count technique that aims to estimate horse populations inhabiting vast areas of sage-steppe habitat. Fertility control field trials also continued in 2009, with close monitoring of individual horses in three populations for a return to fertility and the seasonality of parturition following immunocontraception with porcine zona pellucida (PZP). As FORT research continues to investigate wild horse population estimation techniques and fertility control, scientists are working closely with managers to transfer technology and implement these new techniques to support decisionmaking.

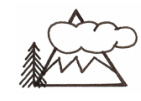

\section{Effects of Roads and Traffic on Wildlife} in the Upper Missouri River Breaks

National Monument. The establishment of the Upper Missouri River Breaks National Monument has offered an opportunity to investigate the effects of roads and traffic on wildlife, habitat, watersheds, and the visual and historical resources of the area. Increasing oil and gas development introduces concerns about the protection of monument resources and potentially amplifies competition among divergent management aims. The objective of this project was to develop quantitative information about one aspect of energy development - vehicular trafficand to provide a baseline for comparison of future change. In FY09, FORT scientists continued to

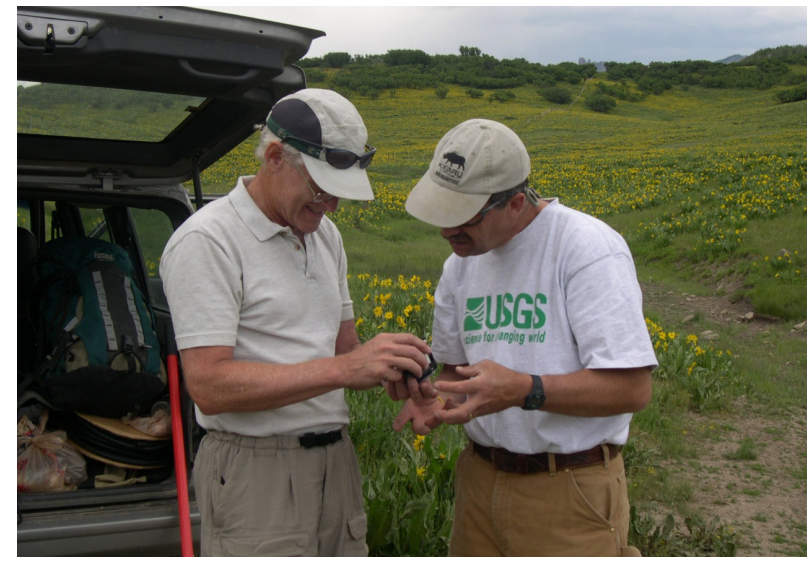

USGS scientists Ray Watts and Doug Ouren prepare to set up a traffic-monitoring device on a road in Upper Missouri River Breaks National Monument. USGS photo. monitor motorized use throughout the established road network, developed automated tools to ensure data quality, and developed models for data analysis. The BLM will use the resultant data and models to assess the impacts of motorized use on wildlife populations and to develop travel management plans for the area.

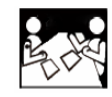

Public Access Management as an Adaptive Wildlife Management Tool. Off-highway vehicle (OHV) use - and more specifically, its effects on wildlife populations across the western United States - continues to be a major issue for land management agencies. The objective of this project is to determine the impacts of OHV use on elk (Cervus canadensis) distribution and habitat use. To address this objective, FORT scientists developed a 20 -site OHV monitoring network and outfitted 50 elk with GPS collars to monitor both the intensity and timing of OHV use in relationship to elk habitat use and movements. In FY09, researchers continued to maintain the OHV monitoring network and to collect location data from elk collars. In addition, they began developing models on elk movement and its relationship to OHV use. They also provided input for USFS, BLM, and NPS travel management planning and BLM Resource Management Plan updates.

White Nose Syndrome in Bats. Over the past three winters, an epizootic disease called White Nose Syndrome (WNS) began devastating populations of hibernating bats in the northeastern United States. The syndrome has quickly spread from a small area in upstate New York to 
an area covering more than 900 square kilometers and 9 states, causing precipitous declines at most known colonies of hibernating bats in affected areas. This type of sudden, widespread, and expanding mortality is completely unprecedented in bats. White Nose Syndrome is named for the presence of a previously unknown, highly invasive white fungus (Geomyces destructans) on affected bats. The FORT response to this issue initially involved helping to coordinate the scientific investigation into the causes and spread of WNS, but recently moved into active field research to establish links between mortality and skin infection by the presumed causative fungus. In particular, FORT regularly consults with biologists in the USFWS, the USGS National Wildlife Health Center, and several State agencies on various aspects of bat ecology as they relate to WNS.

During FY09, FORT helped prepare background materials for congressional hearings, developed a Web site with publicly available information on WNS (see www.fort.usgs.gov/wns), participated in ef-

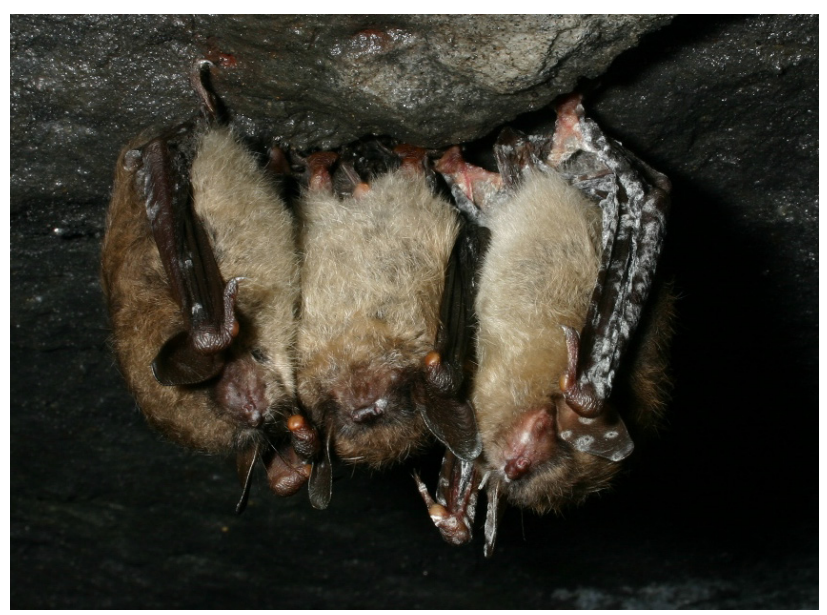

White nose syndrome showing diagnostic white patches on muzzles and wings. Photo by Alan Hicks, New York Department of Environmental Conservation. Used with permission. forts to coordinate Federal and State responses to the problem, worked with European researchers to better understand whether WNS could be caused by an introduced exotic species, and initiated a field study that involved rapidly developing and deploying cuttingedge surveillance camera systems capable of monitoring the behaviors of hibernating bats in deep, dark caves and mines. This study will investigate the hypothesis that $G$. destructans is the primary causative agent of mortality, and that it might be acting on bats by promoting unusual activity and behavior in winter, resulting in the depletion of their energy stores. WNS poses a major threat to four species and subspecies of hibernating cave bats listed under the Federal Endangered Species Act, as well as several previously common species in the Northeast.

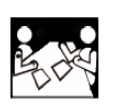

\section{Plague as a Conservation Threat to Imperiled \\ Species. At the recent international symposium} on the ecology of plague and its effect on wildlife

(http://www.fort.usgs.gov/Plague/default.asp? Ad=Plague), FORT presented new information that demonstrates that plague is a conservation threat to the endangered black-footed ferret (Mustela nigripes) and federally threatened Utah prairie dog (Cynomys parvidens) — even when it does not "erupt" into epidemic form. Eruptions of the fatal disease have caused population collapses of prairie dogs and dependent ferret populations in many locations over the years. Research from scientists at FORT and the USFWS indicates that plague may be "maintained" in the wild within colonies of prairie dogs, the primary food of black-footed ferrets, without causing the largescale, rapid die-off of prairie dogs that is commonly observed. Investigators also found that plague management (via flea control or experimental vaccine) improved prairie dog survival even when these die-offs were not observed. Further, plague

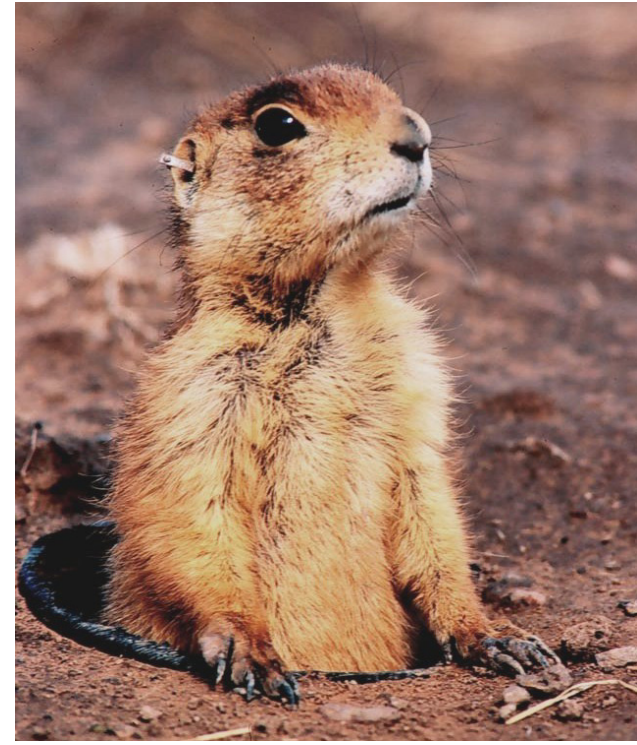

Federally threatened Utah prairie dog showing ear tag. USGS photo by Dean Biggins. 
was rarely detected at these study sites using common diagnostic tests on hundreds of potential rodent hosts and thousands of their fleas, illustrating that lack of detection does not imply low risk. The mechanisms for the bacterium's low-level presence and survival, as well as the absence of a large-scale die-off of prairie dogs, remain under investigation. This information was subsequently published in a special issue of Vector-Borne and Zoonotic Diseases (http://www.liebertonline.com/toc/vbz/10/1) that presents an update of plague in North America and other continents; describes its effects on wildlife, including endangered species; and considers how plague management, including vaccines, can help minimize the devastating impacts to wildlife.
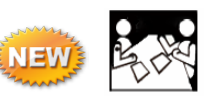

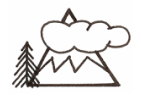

Investigating the Long-Term Variation in the Nutritional Ecology and Genetics of White-Tailed Ptarmigan: Implication for Effects of Climate Change on Alpine Species. As an iconic avian species associated with naturally fragmented alpine habitats, the white-tailed ptarmigan (Lagopus leucurus) is an ideal model of a species that will have limited opportunity to alter their distribution in response to a changing climate. FORT scientists initiated a research project that takes advantage of long-term demographic data for white-tailed ptarmigan on Mt. Evans in Colorado. Completing the first stage of this research, FORT scientists published a manuscript that details temporal variation in white-tailed ptarmigan genetics and foraging ecology in response to climate change. This study provides evidence that white-tailed ptarmigan are good indicators of global climate change, information that is vital to those agencies charged with monitoring and mitigating impacts of climate change on vulnerable species.

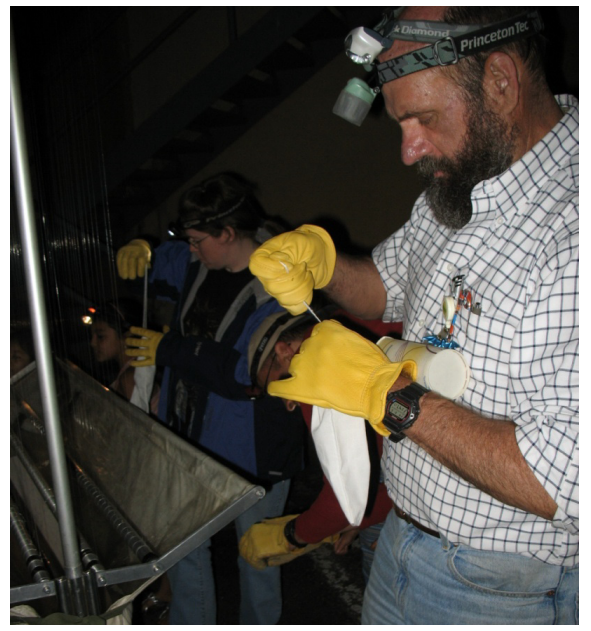

Lead investigator Tom O'Shea and his crew bag bats captured using a harp trap for the Fort Collins commensal bats and rabies transmission study. USGS photo.

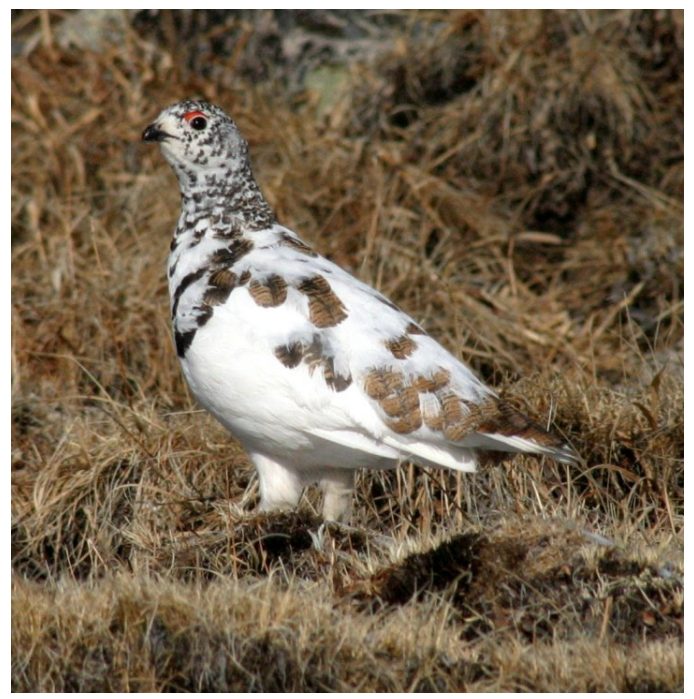

White-tailed ptarmigan on Mt. Evans in Colorado. Photo by Cameron Aldridge, Colorado State University IUSGS.

\section{The Ecology of Rabies Transmission in Commensal \\ Bats. FORT recently completed a study (see}

http://www.fort.usgs.gov/news/news_story.asp? WebID=070514) investigating the relationships among the ecology of commensal bats (those that roost in human-occupied buildings), the dynamics of rabies virus infections, and public health surveillance measures against rabies exposure. The research focused on big brown bats (Eptesicus fuscus) living in houses and commercial buildings in Fort Collins, Colo. This species occurs nationwide and is the most commonly submitted bat for rabies diagnostic examinations nationally; more people are potentially exposed to rabies from this bat than from any other species. Investigators documented host bat population dynamics, seasonal reproduction strategies, migration, and hibernation. In Fort Collins, these bats were found to be highly exploitative of buildings as roosts for breeding in summer, and very adaptable to the urbanizing environment. It was also discovered that these and other 
bats were unlike other mammals in that they were frequently exposed to rabies but usually resistant to productive infections, instead showing a high prevalence of protective antibodies.

These and other study results have been widely published: throughout 2009 the project produced 20 journal publications, 2 dissertations, and 3 master's theses. These results have important implications for public health programs and for conservation of bat populations. The study also sets the stage for a better understanding of the potential range of host-virus parameters that may be important to the emergence of other viruses in bats (bats have been the source for viruses leading to diseases with human health consequences, such as Ebola, SARS, and Nipah), a topic of increasing concern. This multidisciplinary investigation was funded by the National Science Foundation/National Institutes of Health's Ecology of Infectious Diseases Program and involved Colorado State University researchers from several departments, USGS bat ecologists and human dimensions experts at FORT, virologists at the Centers for Disease Control and Prevention in Atlanta, and other cooperators.

\section{Sharing the Wealth: Access to Products}

\section{Products and Publications}

During FY09, FORT scientists delivered 123 products, 94 of which were publications (with more in press). For a list of all our products, many of which are available online, visit http://www.fort.usgs.gov/Products/. Appendix 1 lists publications from FY09 by USGS program element; appendix 2 does the same for other types of products.

\section{Sharing the Wealth: Access to Expertise}

\section{Workshops}

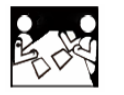

Symposium on the Ecology of Plague and Its Effects on Wildlife. Although much is known about plague and the bacterium responsible for historic human plague endemics, less is known regarding its effect on wildlife. For the few wildlife species where the effects of plague have been studied, there is cause for alarm as important questions have been raised regarding how plague might be affecting conservation efforts in North America, in general. These questions were addressed in November 2008 at an international symposium on the ecology of plague and its effects on wildlife (http://www.fort.usgs.gov/Plague/default.asp? Ad=Plague). The symposium was held in Fort Collins, Colo., and hosted by FORT, Colorado State University, the USFWS, and the Centers for Disease Control.

Topics explored at the symposium included the maintenance dynamics of plague in the environment; the influence of environmental factors and landscape ecology on plague; the role of rodents and vector species in transmitting the disease; genetics and evolution; the challenges of detecting plague in rodent hosts; and the effectiveness of plague control strategies, including development of an experimental vaccine. Most importantly, the symposium explored the impacts of plague on wildlife populations and the consequences for conservation of imperiled species, and it raised awareness in the natural resource management community of this persistent and real threat to many wildlife species of conservation concern. A special issue of the journal Vector-Borne and Zoonotic Diseases, presenting articles and abstracts from the symposium, was released in February 2010 (see

(http://www.liebertonline.com/toc/vbz/10/1). 


\section{Training}

Webinar: An Introduction to the Fundamentals of Linear Quantile Regression in R. A FORT scientist presented a 2-hour webinar on March 12, 2009, on the fundamentals of linear quantile regression and implementing the models in the free statistical package called " $\mathrm{R}$ ". The webinar was attended by 80 participants via the Internet, including scientists and statisticians from Federal, tribal, and State agencies; universities; nongovernmental organizations; and people from the Americas and Europe. This webinar was presented and recorded as a special topic under the Learn-R webinar series, available on the USGS Web site at http://www.fort.usgs.gov/BRDScience/LearnR.htm. Quantile regression provides a comprehensive statistical approach for estimating relationships between a response variable and various predictor variables. It is especially useful in ecological and biological applications where heterogeneity in responses is common because of missing information on some important processes. Quantile regression has many potential applications to modeling and predicting organism responses to their environment, density-dependent processes, allometric growth in biological organisms, changes in phenology, effects of contaminants on organisms, equivalence testing, and modeling of flow records in hydrology. Because the quantile regression methodology is relatively new and unfamiliar to most scientists, instructing other scientists in the implementation of quantile regression is a fundamental activity supporting other FORT investigations, such as linking changes in the body condition of fish to spatial and temporal changes in their aquatic environment.

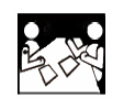

\section{Brown Treesnake Rapid Response Team Training Workshops. Brown} Treesnakes (Boiga irregularis) have caused and continue to cause major problems for the ecology, economy, and quality of life on Guam. In 2002, a multi-agency Rapid Response Team (RRT) led by the USGS (http://www.fort.usgs.gov/StalkingSnakes/) was established to assist in the detection and capture of Brown Treesnakes spotted on recipient islands following accidental transport to these islands from Guam. Since its creation, the RRT has conducted 2-5 training courses annually and 21 off-Guam field operations. During FY09, two field operations were conducted, one on Soong Island on Ulithi Atoll, Yap State, Federated States of Micronesia (FSM), and one on Saipan near the Saipan International Airport. Several cooperating agencies assisted with this operation. At the end of FY09, the RRT consisted of 79 members located throughout the Pacific region and the United States mainland.

The RRT has incorporated research results from FORT studies investigating means to improve snake detectability at low densities, testing effectiveness of control tools in rodent-rich environments, and predicting movements of snakes accidentally translocated to other islands. In FY09, RRT training included one 18-day course on Guam for new team members, one 5-day course on Oahu for $18 \mathrm{Ha}$ waiian Islands staff, and one 5-day refresher course on Guam. The RRT also provided biosecurity training as part of a DOD-sponsored, All-Hazards/Terrorism subject matter exchange held at Colonia, 
Yap State, FSM. The RRT assisted with Secretariat of the Pacific Community/USDA Animal and Plant Health Inspection Service (APHIS) quarantine training for Pacific Islanders on Guam, and with Pacific Invasives Learning Network biosecurity training for Pacific Islanders on Oahu.

Outreach efforts included 14 presentations on Guam to 447 people, including media representatives from Okinawa and Korea, and two regional island outreach trips, one to the Republic of Palau and the other to Yap State, FSM. Cooperators include the DOI Office of Insular Affairs, the USFWS, Hawaiian Island Invasive Species Committees, the Coordinating Group on Alien Pest Species, the DOD, the Guam Division of Aquatic and Wildlife Resources, USDA Wildlife Services and APHIS, the Hawaii Department of Agriculture, and the Hawaii Department of Forestry and Wildlife. Additional quarantine, agriculture, and natural resources cooperators include officials from the FSM, the Republic of the Marshall Islands, the Commonwealth of the Northern Mariana Islands, and the Republic of Palau.

Negotiation Training for Natural Resources Professionals. Natural resource managers often face decisions that are complex and involve many parties. With an increasing emphasis on collaboration and stakeholder involvement, it is essential that resource managers acquire and refine negotiation skills. Social scientists at FORT have conducted research about natural resource conflict resolution and negotiation since the 1980s and provide training courses that draw in part from these findings. The courses are well grounded in classic negotiation theory and enriched by the instructors' research. During FY 2009, the class entitled Negotiation Skills for Natural Resource Professionals: Building a Foundation (http://www.fort.usgs.gov/Products/Training/NegTraining/) was offered twice, in May and June. The May class was requested by the USFWS and was held at the National Conservation Training Center in Shepherdstown, W. Va. Students came from a variety of Federal agencies (including the USGS, USFWS, NPS, BLM, Reclamation, USFS, Minerals Management Service, and Natural Resource Conservation Service) and State agencies (the Colorado Department of Public Health and Environment and the Wyoming Department of Environmental Quality).

In September 2009, FORT scientists offered the advanced negotiation training class, Strategies and Tactics for the Experienced Natural Resource Negotiator (http://www.fort.usgs.gov/Products/Training/NegTraining). Class evaluations for all of these courses were very positive, and feedback from previous or returning students indicates that the skills gained in these classes are extremely valuable and help managers make informed decisions.

\section{Making a Difference (Customer Satisfaction)}

\section{Letters, Emails}

- From Jennifer Frey, Associate Editor, The Southwestern Naturalist regarding FORT scientist Ernest Valdez' peer review of a submitted manuscript:

\section{Dear Ernie,}

I received your review of the manuscript, which was submitted for possible publication in The Southwestern Naturalist, and I want to thank you for your work. Your efforts aid the Southwestern Association of Naturalists in publishing a journal of outstanding quality, and I appreciate your help in this process. Thanks again! 
- From Loren K. Ammerman, Associate Professor, Department of Biology, Angelo State University (Texas Tech University System), regarding FORT scientist Ernest Valdez' assistance to the authors of Bats of Texas, soon to be published:

Thank you so much!! That is exactly the perspective I needed. ... Thanks for taking the time to edit this. Your descriptions/comments were very helpful. I owe you a favor.

- From Lisa Angeloni, Assistant Professor, Department of Biology, Colorado State University, regarding FORT scientist Dean Biggins' review of a graduate student's paper on stress in blackfooted ferrets.

Dean, I just wanted to let you know how much we appreciate your input on Sharon's drafts. Your comments are always very thoughtful and reflect a lot of knowledge about ferrets and, more importantly, about science in general. Your most recent responses on the stress paper were particularly well put. Sharon is very lucky to have your input on her thesis.

- From Jullian O'Connell, Chief of the USGS Enterprise Information and Investment program, regarding FORT scientist Phadea Ponds' work as the USGS Information Collection Clearance Officer (ICCO):

Phadrea has gone above and beyond to provide support for the USGS Enterprise Information and Investment program serving as the USGS Information Collections Clearance Officer (ICCO). DOI recently reported that Phadrea is "...producing what we need and then some. She is already providing a quantity and quality of review and action related to the Paperwork Reduction Act (PRA) and information collection matters beyond that which any previous USGS ICCO has ever provided." Phadrea's efforts to quickly come up to speed on this relatively new area have paid significant dividends for USGS with both DOI and OMB [Office of Management and Budget]. Phadrea's diligence in identifying information collections across the USGS has resulted in significant improvements in USGS compliance with the PRA. In addition, Phadrea has generously provided her expertise by working with the USGS program offices and her PRA colleagues in her usual polite and professional manner. Phadrea's extraordinary efforts have been greatly appreciated. Thank you Phadrea!

- From Keevin Minami, Land Vertebrates Specialist, Hawaii Department of Agriculture, on the work of invasive species scientist Bob Reed:

The Plant Quarantine Branch of the Hawaii Department of Agriculture regulates the importation and possession of all non-domestic animals into the State of Hawaii by referring to various lists of allowable animals that are maintained by the Board of Agriculture. Preventing the introduction of invasive species is essential to protecting our fragile environment. 
Dr. Reed has assisted Plant Quarantine on numerous occasions with the identification of various reptiles ranging from snakes, lizards, turtles and skinks. His timely responses to requests for information and identification of animals showed his willingness to work with other agencies. Also, his ability to correctly identify the species of these animals sometimes through emailed photographs confirmed his expertise in his field of study and his extensive knowledge.

I look forward to working with Dr. Reed in the future on the Brown treesnake project, which is also crucial to the prevention and spread of this extremely invasive reptile species throughout the Pacific Islands. Dr. Reed's service to Plant Quarantine has been invaluable and we certainly appreciate his expertise and willingness to work with our program.

- From Skip Snow, Wildlife Biologist, Everglades National Park, on Bob Reed's work with invasive giant constrictor snakes:

In recent years Dr. Robert Reed has made significant contributions towards our understanding of non-native invasive snakes, especially the Burmese python, and other reptiles in South Florida. Everglades National Park has consulted frequently with Dr. Reed in all manner of reptile related subject matter, including species identification, general biology, ecology, husbandry, rapid assessment, invasive species impacts, and management strategies such as visual searching, trap design and deployment, and bounties.

His written and verbal responses have been objective, timely, thorough, yet to the point. His technical advice and critical reviews reflect a solid understanding of the literature and a broad national and international network of professional contacts. Site visits have been invaluable, performed professionally with enthusiasm and efficiency.

Dr. Reed's contributions to the recently completed "Giant Constrictors: Biological Profiles and Importation Risk Assessment for Nine Large Species of Pythons, Anacondas, and the Boa Constrictor, " co-authored with Dr. Gordon Rodda, have exceeded Everglades National Park expectations in both quantity and quality of work. Everglades National Park will not hesitate to call upon Dr. Reed for continued insight and contributions towards science-based ecosystem management in the face of the growing threat of non-native invasive species.

- Feedback from two international snake specialists on the Giant Constrictor Risk Assessment Report by FORT scientists Bob Reed and Gordon Rodda:

From Prof. Graham J. Alexander, Animal, Plant and Environmental Sciences, University of the Witwatersrand, South Africa:

Hi Robert

First of all, thank you so much for the link. I have download[ed] the pdf and am very impressed - haven't read it all, but the bits that I have read are great. Well done - this is a very important contribution. 
From Dr. Lutz Dirksen, Reptile + Animal Presentation, Berlin, Germany

(http://www.anakondas.de/cms/front_content.php)

Dear Bob,

Thank you for sending the risk assessment! It is really an extensive work. I am impressed. I will read it asap. Maybe you should print it and sell it as a book?

- From Julie Tyrrell, a home-school mom, on the response of elementary children to a presentation by FORT scientist and bird biologist Janet Ruth:

I would just like to express my thanks again to you for speaking to the kids at the Albuquerque Homeschool Science Co-Op. Your presentation was a wonderful way to end our unit on bird migration. The kids as well as myself and other moms learned a lot about studying birds in their natural habitats and tracking bird migration. My middle son, Matthew, came home and described in detail the "S" shape radar form of birds migrating over the water and then having to turn around and come back. It was a great morning! Thanks again.

- From Larry L. Norris, NPS Southwest Research Coordinator, Desert Southwest CESU, University of Arizona, to FORT scientist Janet Ruth:

Thank you very much for the Biological Technical Publication MOLT AND AGING CRITERIA FOR FOUR NORTH AMERICAN GRASSLAND PASSERINES. This is a wonderful addition to my reference library. It will get studied and used.

I appreciate your willingness to share so much information across agencies and NGOs, and your determination to get it in the hands of the field people.

- From two recipients of Management and Research Applications of Long-Range Surveillance Radar Data for Birds, Bats, and Flying Insects, a fact sheet on use of radar for tracking migratory aerofauna movements coauthored by FORT scientist Janet Ruth:

Jeffrey Buler, Research Scientist, Department of Entomology and Wildlife Ecology, University of Delaware:

Thanks for passing that along Janet. I'd give you an extra pat - you have really helped promote awareness of radar biology to a great extent!

Bill Howe, USFWS Region 2 Migratory Bird Office:

Janet - this is an excellent fact sheet! Thanks for sending, and congratulations to you and the others for a job well done. I'll be sending this out to all of our Refuge and ES [Endangered Species] field folks. 
Non-USGS Awards

- Pat Anderson received the BLM Citizen's Award for Exceptional Service from the BLM High Desert District in Wyoming. This award is associated with the coordination activities Pat does related to the Wyoming Landscape Conservation Initiative.

- Tom Stohlgren, Catherine Jarnevich, and Tracy Holcombe received the Department of the Interior Partners in Conservation Award, presented by Secretary of the Interior Ken Salazar, for "Partnerships in Advanced Invasive Species Modeling" in recognition of outstanding conservation achievements attained through collaboration and partnerships with others, May 2009.

Additionally, appendix 3 lists pertinent committee and board appointments and invited presentations from FY09.

\section{For More Information}

To learn more about FORT research staff, projects, science publications and products, news, and events, visit www.fort.usgs.gov. 


\section{Appendix 1: FORT Publications Delivered in FY 2009}

\begin{tabular}{|c|c|}
\hline $\begin{array}{l}\text { Publication } \\
\text { Type }\end{array}$ & Citation \\
\hline \multicolumn{2}{|r|}{ Biological Informatics (BIO) } \\
\hline Journal Article & $\begin{array}{l}\text { Peinetti, H.R., B.W. Baker, and M.C. Coughenour. 2009. Simulation modeling to understand how } \\
\text { selective foraging by beaver can drive the structure and function of a willow community. Ecological } \\
\text { Modelling 220(7): } 998-1012 \text {. }\end{array}$ \\
\hline Pages in Book & $\begin{array}{l}\text { Stohlgren, T.J. and C.S. Jarnevich. 2009. Risk assessment of invasive species. In: M.N. Clout and } \\
\text { P.A. Williams (eds.). Invasive Species Management: A Handbook of Principles and Techniques. } \\
\text { New York: Oxford University Press. p. 19-35. }\end{array}$ \\
\hline $\begin{array}{l}\text { USGS Open-File } \\
\text { Report }\end{array}$ & $\begin{array}{l}\text { Wilson, J.T. (compiler). 2009. Fort Collins Science Center: Fiscal Year } 2008 \text { Accomplishments: U.S. } \\
\text { Geological Survey Open-File Report 2009-1107. } 58 \text { p. }\end{array}$ \\
\hline \multicolumn{2}{|r|}{ Terrestrial, Freshwater, and Marine Ecosystems (ECO) } \\
\hline Journal Article & $\begin{array}{l}\text { Aldridge, C.L. and M.S. Boyce. 2008. Accounting for fitness: Combining survival and selection } \\
\text { when assessing wildlife-habitat relationships. Israel Journal of Ecology and Evolution 54(3-4): 389- } \\
419 \text {. }\end{array}$ \\
\hline Journal Article & $\begin{array}{l}\text { Allen, C.D. 2009. Climate-induced forest dieback: An escalating global phenomenon? Unasylva } \\
\text { 231/232 60(1-2): 43-49. }\end{array}$ \\
\hline $\begin{array}{l}\text { USGS Scientific } \\
\text { Investigations Re- } \\
\text { port }\end{array}$ & $\begin{array}{l}\text { Auble, G.T., C.L. Holmquist-Johnson, J.T. Mogen, L.R. Kaeding, and Z.H. Bowen. 2009. Relation } \\
\text { between streamflow of Swiftcurrent Creek, Montana, and the geometry of passage for Bull Trout } \\
\text { (Salvelinus confluentus): U.S. Geological Survey Scientific Investigations Report 2009-5100. } 18 \text { p. }\end{array}$ \\
\hline $\begin{array}{l}\text { USGS Open-File } \\
\text { Report }\end{array}$ & $\begin{array}{l}\text { Auble, G.T., M. Wondzell, and C. Talbert. 2009. Decision support system for evaluation of Gunni- } \\
\text { son River flow regimes with respect to resources of the Black Canyon of the Gunnison National } \\
\text { Park: U.S. Geological Survey Open-File Report 2009-1126. } 24 \text { p. }\end{array}$ \\
\hline Pages in Report & $\begin{array}{l}\text { Baron, J.S., L. Christensen, C. Tague, C. Allen, D. Peterson, D. McKenzie, D. Fagre, and N. Ste- } \\
\text { phenson. 2009. Addressing the vulnerability of western mountain ecosystems and water resources to } \\
\text { climate change with RHESSys, the Regional Hydro-Ecological Simulation System. In: S.R. Brady } \\
\text { (ed.). Proceedings of the Second All-USGS Modeling Conference, February 11-14, 2008-Painting } \\
\text { the Big Picture. U.S. Geological Survey Scientific Investigations Report 2009-5013. p. } 2 \text {. }\end{array}$ \\
\hline Journal Article & $\begin{array}{l}\text { Baron, J.S., S.H. Julius, J.M. West, L.A. Joyce, G. Blate, C.H. Peterson, M. Palmer, B.D. Keller, P. } \\
\text { Kareiva, J.M. Scott, and B. Griffith. 2008. Some guidelines for helping natural resources adapt to } \\
\text { climate change. IHDP Update 2: 46-52. }\end{array}$ \\
\hline USGS Fact Sheet & $\begin{array}{l}\text { Baron, J.S., D. Peterson, and J. Wilson. 2008. Western Mountain Initiative: Predicting ecosystem } \\
\text { responses to climate change: U.S. Geological Survey Fact Sheet 2008-3093. } 2 \text { p. }\end{array}$ \\
\hline Journal Article & $\begin{array}{l}\text { Baron, J.S., T.S. Schmidt, and M.D. Hartman. 2009. Climate-induced changes in high elevation } \\
\text { stream nitrate dynamics. Global Change Biology 15: 1777-1789. }\end{array}$ \\
\hline Proceedings & $\begin{array}{l}\text { Bentz, B., J. Logan, J. MacMahon, C. Allen, et al. 2009. Bark beetle outbreaks in Western North } \\
\text { America: Causes and consequences. Chicago, IL: University of Utah Press. } 42 \text { p. }\end{array}$ \\
\hline $\begin{array}{l}\text { USGS Open-File } \\
\text { Report }\end{array}$ & $\begin{array}{l}\text { Bowen, Z.H., C.L. Aldridge, P.J. Anderson, T.J. Assal, L.A. Baer, S. Bristol, N.B. Carr, G.W. } \\
\text { Chong, J.E. Diffendorfer, B.C. Fedy, S.L. Homer, D. Manier, M.J. Kauffman, N. Latysh, C.P. } \\
\text { Melcher, K.A. Miller, J. Montag, et al. 2009. U.S. Geological Survey Science for the Wyoming } \\
\text { Landscape Conservation Initiative-2008 Annual Report: U.S. Geological Survey Open-File Report } \\
\text { 2009-1201. } 83 \text { p. }\end{array}$ \\
\hline Journal Article & $\begin{array}{l}\text { Bowman, W.D., C.C. Cleveland, L. Halada, J. Hresko, and J.S. Baron. 2008. Negative impact of ni- } \\
\text { trogen deposition on soil buffering capacity. Nature Geoscience 1: 767-770. }\end{array}$ \\
\hline
\end{tabular}




\begin{tabular}{|c|c|}
\hline Journal Article & $\begin{array}{l}\text { Breshears, D.D., O.B. Myers, C.W. Meyer, F.J. Barnes, C.B. Zou, C.D. Allen, N.G. McDowell, and } \\
\text { W.T. Pockman. 2009. Tree die-off in response to global-change-type drought: Mortality insights } \\
\text { from a decade of plant water potential measurements. Frontiers in Ecology and the Environment } \\
7(4): 185-189 \text {. }\end{array}$ \\
\hline Journal Article & $\begin{array}{l}\text { Breshears, D.D., J.J. Whicker, C.B. Zou, J.P. Field, and C.D. Allen. 2009. A conceptual framework } \\
\text { for dryland aeolian sediment transport along the grassland-forest continuum: Effects of woody plant } \\
\text { canopy cover and disturbance. Geomorphology 105(1-2): } 28-38 \text {. }\end{array}$ \\
\hline $\begin{array}{l}\text { USGS Open-File } \\
\text { Report }\end{array}$ & $\begin{array}{l}\text { Erickson, H.J., C.L. Aldridge, and N.T. Hobbs. 2009. Progress Report: Stratton Ecological Research } \\
\text { site: An experimental approach to assess effects of various grazing treatments on vegetation and } \\
\text { wildlife communities across managed burns and habitat controls: U.S. Geological Survey Open-File } \\
\text { Report } 2009-1016.15 \text { p. }\end{array}$ \\
\hline Journal Article & $\begin{array}{l}\text { Esposito, R.M.M, S.A. Spaulding, D.M. McKnight, B. Van de Vijver, K. Kopalova, D. Lubinski, B. } \\
\text { Hall, and T. Whittaker. 2008. Inland diatoms from the McMurdo Dry Valleys and James Ross Island, } \\
\text { Antarctica. Botany } 86(12): 1378-1392 .\end{array}$ \\
\hline Report & $\begin{array}{l}\text { Fagre D.B., C.W. Charles, C.D. Allen, C. Birkeland, F.S. Chapin III, P.M. Groffman, G.R Guntens- } \\
\text { pergen, A.K. Knapp, A.D. McGuire, P.J. Mulholland, D.P.C. Peters, D.D. Roby, and G. Sugihara. } \\
\text { 2009. Synthesis and Assessment Product 4.2: Thresholds of climate change in Ecosystems. A Report } \\
\text { by the U.S. Climate Change Science Program and the Subcommittee on Global Change Research. } \\
\text { U.S. Geological Survey, Reston, Va. } 157+\text { p. }\end{array}$ \\
\hline Journal Article & $\begin{array}{l}\text { Friedman, J.M., J.E. Roelle, J.F. Gaskin, A.E. Pepper, and J.R. Manhart. 2008. Latitudinal variation } \\
\text { in cold hardiness in introduced Tamarix and native Populus. Evolutionary Applications 1(4): 598- } \\
607 .\end{array}$ \\
\hline Abstract & $\begin{array}{l}\text { Holloway, J.M., C.A. Stricker, and J. Baron. 2009. Role of soil biogeochemistry in sequestration of } \\
\text { Hg and Pb from atmospheric deposition in an alpine watershed, Rocky Mountain National Park, CO. } \\
\text { Abs. In: Proceedings, } 2009 \text { Portland GSA Annual Meeting, October 18-21, 2009, Portland, OR. } \\
\text { Washington, DC: Geological Society of America. p. 1. }\end{array}$ \\
\hline $\begin{array}{l}\text { USGS Open-File } \\
\text { Report }\end{array}$ & $\begin{array}{l}\text { Homer, C.G., C.L. Aldridge, D.K. Meyer, M.J. Coan, and Z.H. Bowen. 2009. Multiscale sagebrush } \\
\text { rangeland habitat modeling in southwest Wyoming: U.S. Geological Survey Open-File Report 2008- } \\
1027.14 \text { p. }\end{array}$ \\
\hline Journal Article & $\begin{array}{l}\text { Kotliar, N.B., E.W. Reynolds, and D.H. Deutschman. 2008. American three-toed woodpecker re- } \\
\text { sponse to burn severity and prey availability at multiple spatial scales. Fire Ecology 4(2): 26-45. }\end{array}$ \\
\hline Journal Article & $\begin{array}{l}\text { Miller, J.R. and J.M. Friedman. 2009. Influence of flow variability on floodplain formation and de- } \\
\text { struction, Little Missouri River, North Dakota. Geological Society of America Bulletin 121(5-6): } \\
\text { 752-759. }\end{array}$ \\
\hline Abstract & $\begin{array}{l}\text { O'Shea, T.J. 2009. Fifteen years further down the road: An arm-chair perspective on advances and } \\
\text { changes in Sirenian biology and conservation. Abs. In: Proceedings, } 2009 \text { International Sirenian } \\
\text { Conservation Conference, Atlanta, Georgia, 23-24 March, 2009. The Georgia Aquarium, Atlanta, } \\
\text { GA, and the Marine Mammal Research and Conservation Program, Harbor Branch Oceanographic } \\
\text { Institute at Florida Atlantic University, Fort Pierce, FL. p. 1. }\end{array}$ \\
\hline Journal Article & $\begin{array}{l}\text { Romme, W.H., C.D. Allen, J.D. Bailey, W.L. Baker, B.T. Bestelmeyer, P.M. Brown, K.S. Eisenhart, } \\
\text { M.L. Floyd, D.W. Huffman, B.F. Jacobs, R.F. Miller, E.H. Muldavin, T.W. Swetnam, R.J. Tausch, } \\
\text { and P.J. Weisberg. 2009. Historical and Modern Disturbance Regimes, Stand Structures, and Land- } \\
\text { scape Dynamics in Piñon-Juniper Vegetation of the Western United States. Rangeland Ecology \& } \\
\text { Management 62(3): 203-222. }\end{array}$ \\
\hline Journal Article & $\begin{array}{l}\text { Sanderson, J.S., N.B. Kotliar, and D. Steingraeber. 2008. Opposing environmental gradients govern } \\
\text { vegetation zonation in an intermountain playa. Wetlands 28(4): 1060-1070. }\end{array}$ \\
\hline Report & $\begin{array}{l}\text { U.S. Environmental Protection Agency. 2008. Integrated Science Assessment (ISA) for Oxides of } \\
\text { Nitrogen and Sulfur Ecological Criteria (Final Report). U.S. Environmental Protection Agency } \\
\text { EPA/600/R-08/082F. http://cfpub.epa.gov/ncea/cfm/recordisplay.cfm?deid=201485 }\end{array}$ \\
\hline
\end{tabular}




\begin{tabular}{|c|c|}
\hline USGS Fact Sheet & $\begin{array}{l}\text { Wilson, J.T., C. Melcher, and Z. Bowen. 2008. Fort Collins Science Center: Ecosystem Dynamics } \\
\text { Branch: U.S. Geological Survey Fact Sheet 2008-3100. } 4 \text { p. }\end{array}$ \\
\hline $\begin{array}{l}\text { USGS Open-File } \\
\text { Report }\end{array}$ & $\begin{array}{l}\text { Zeigenfuss, L.C., D. Binkley, G.A. Tuskan, W.H. Romme, T. Yin, S. DiFazio, and F.J. Singer. } 2008 . \\
\text { Aspen ecology in Rocky Mountain National Park: Age distribution, genetics, and the effects of elk } \\
\text { herbivory: U.S. Geological Survey Open-File Report 2008-1337. } 52 \text { p. }\end{array}$ \\
\hline \multicolumn{2}{|r|}{ Fisheries: Aquatic and Endangered Resources (FAER) } \\
\hline Abstract & $\begin{array}{l}\text { Carpenter, J. 2009. Results of monitoring and development activities for native fish sanctuaries in the } \\
\text { lower Colorado River Basin, abs. In: Proceedings, Colorado River Aquatic Biologists Annual Meet- } \\
\text { ing, January 7-8, 2009, Laughlin, NV. p. } 1 .\end{array}$ \\
\hline $\begin{array}{l}\text { USGS Scientific } \\
\text { Investigations Re- } \\
\text { port }\end{array}$ & $\begin{array}{l}\text { Hanson, L., R. Schrock, T.J. Waddle, J. Duda, and W.A. Lellis. 2009. USGS river ecosystem model- } \\
\text { ing: Where we are, how did we get here, and where are we going? A report from the USGS River } \\
\text { Ecosystem Modeling Work Group: U.S. Geological Survey Scientific Investigations Report 2009- } \\
5018.81 \text { p. }\end{array}$ \\
\hline Journal Article & $\begin{array}{l}\text { McCullough, D.A., J.M. Bartholow, H.I. Jager, R.L. Beschta, E.F. Cheslak, M.L. Deas, J.L. Eber- } \\
\text { sole, J.S. Foott, S.L. Johnson, K.R. Marine, M.G. Mesa, J.H. Petersen, Y. Souchon, K.F. Tiffan, and } \\
\text { W.A. Wurtsbaugh. 2009. Research in Thermal Biology: Burning Questions for Coldwater Stream } \\
\text { Fishes. Reviews in Fisheries Science 17(1): 90-115. }\end{array}$ \\
\hline Journal Article & $\begin{array}{l}\text { Mueller, G. and J. Carpenter. 2008. Bringing back the bonytail and the razorback. FWS Endangered } \\
\text { Species Bulletin 33(3): 20-22. }\end{array}$ \\
\hline Abstract & $\begin{array}{l}\text { Rinella, D.J., M.S. Wipfli, C.A. Stricker, and R. Heintz. 2009. The relationship between spawning } \\
\text { salmon abundance and the fitness of stream-dwelling fishes, Kenai Peninsula, Alaska. Abs. In: Pro- } \\
\text { ceedings, Western Division of the American Fisheries Society, } 2009 \text { Annual Meeting: Evolution of } \\
\text { the western landscape--balancing habitat, land, and water management for fish, Albuquerque, NM, } \\
\text { May 3-7, 2009. Bethesda, MD: American Fisheries Society. p. 88-89. }\end{array}$ \\
\hline Abstract & $\begin{array}{l}\text { Stricker, C.A., B.A. Murry, D. Clapp, and D.G. Uzarski. 2009. Historical food web changes in Lake } \\
\text { Michigan inferred from isotopic analysis of archived yellow perch scales. Abs. In: Proceedings, } \\
\text { NABS 57th Annual Meeting, May 16-23, 2009, Grand Rapids, MI. Wolfville, Nova Scotia: North } \\
\text { American Benthological Society. p. 1. }\end{array}$ \\
\hline \multicolumn{2}{|r|}{ Invasive Species (INV) } \\
\hline Journal Article & $\begin{array}{l}\text { Carter, G.A., K.L. Lucas, G.A. Blossom, C.L. Lassitter, D.M. Holiday, D.S. Mooneyhan, D.R. Fa- } \\
\text { string, T.R. Holcombe, and J.A. Griffith . 2009. Remote sensing and mapping of Tamarisk along the } \\
\text { Colorado River, USA: A comparative use of summer-acquired hyperion, Thematic Mapper and } \\
\text { QuickBird Data. Remote Sensing 1(3): 318-329. }\end{array}$ \\
\hline Journal Article & $\begin{array}{l}\text { Evangelista, P.H., T.J. Stohlgren, J.T. Morisette and S. Kumar. 2009. Mapping invasive tamarisk } \\
\text { (Tamarix): a comparison of single-scene and time-series analyses of remotely sensed data. Remote } \\
\text { Sensing 1(3): 519-533. }\end{array}$ \\
\hline Journal Article & $\begin{array}{l}\text { Fornwalt, P.J., M.R. Kaufmann, L.S. Huckaby, and T.J. Stohlgren. 2009. Effects of past logging and } \\
\text { grazing on understory plant communities in a montane Colorado forest. Plant Ecology 203(1): 99- } \\
109 .\end{array}$ \\
\hline Abstract & $\begin{array}{l}\text { Graham, J., C. Jarnevich, E. Sellers, T.J. Stohlgren, and G. Newman. 2009. Results from creating a } \\
\text { global system for invasive species data sharing abs. In: Proceedings, 94th Ecological Society of } \\
\text { America Annual Meeting, August 2-7, 2009, Albuquerque, NM. Washington, DC: Ecological Sociey } \\
\text { of America. p. } 1 \text {. }\end{array}$ \\
\hline Abstract & $\begin{array}{l}\text { Holcombe, T.R., C.S. Jarnevich, and T.J. Stohlgren. 2009. Potential habitat modeling for a new cli- } \\
\text { mate. Abs. In: Proceedings, 94th Ecological Society of America Annual Meeting, August 2-7, 2009, } \\
\text { Albuquerque, NM. Washington, DC: Ecological Society of America. p. 1. }\end{array}$ \\
\hline Pages in Book & $\begin{array}{l}\text { Holcombe, T. and T.J. Stohlgren. 2009. Detection and early warning of invasive species. In: M.N. } \\
\text { Clout and P.A. Williams (eds.). Invasive Species Management: A Handbook of Principles and Tech- } \\
\text { niques. New York: Oxford University Press. p. 36-46. }\end{array}$ \\
\hline
\end{tabular}




\begin{tabular}{|c|c|}
\hline Pages in Book & $\begin{array}{l}\text { Jarnevich, C.J., and T.J. Stohlgren. 2009. Temporal management of invasive species. In: Inderjit } \\
\text { (ed.). Management of Invasive Weeds. Dordrecht, Germany: Springer. p. 103-122. }\end{array}$ \\
\hline Abstract & $\begin{array}{l}\text { Jarnevich, C.S. and J.T. Morisette. 2009. Iterative modeling for invasive species abs. In: Proceed- } \\
\text { ings, 94th Ecological Society of America Annual Meeting, August 2-7, 2009, Albuquerque, NM. } \\
\text { Washington, DC: Ecological Society of America. p. 1. }\end{array}$ \\
\hline Journal Article & $\begin{array}{l}\text { Kumar, S. and T.J. Stohlgren. 2009. Maxent modeling for predicting suitable habitat for threatened } \\
\text { and endangered tree Canacomyrica monticola in New Caledonia. Journal of Ecology and The Natu- } \\
\text { ral Environment 1(4): 94-98. }\end{array}$ \\
\hline Journal Article & $\begin{array}{l}\text { Kumar, S., S.E. Simonson, and T.J. Stohlgren. 2009. Effects of spatial heterogeneity on butterfly } \\
\text { species richness in Rocky Mountain National Park, Colorado, USA. Biodiversity and Conservation } \\
\text { 18(3): 739-763. }\end{array}$ \\
\hline Abstract & $\begin{array}{l}\text { Morisette, J., N. Benson, K. Paintner, P. Ma, M. Rocca, S. Kumar, A. Swanson, C. Jarenvich, T. } \\
\text { Stohlgren, P. Lineback, A. Demetry, J. Allen, A. Rodman, C. McClure, T. Caprio, J. Silverman, and } \\
\text { N. Most. 2009. Evaluation of Ensemble Habitat Mapping to support National Park Service decisions } \\
\text { on the fire management and invasive plant species control. Abs. In: Proceedings, Rethinking Pro- } \\
\text { tected Areas in a Changing World: The } 2009 \text { George Wright Society Biennial Conference on Parks, } \\
\text { Protected Areas, and Cultural Sites, March 1-5, 2009, Portland, OR. Hancock, MI: George Wright } \\
\text { Society. p. 1. }\end{array}$ \\
\hline Journal Article & $\begin{array}{l}\text { Morisette, J.T., A.D. Richardson, A.K. Knapp, J.I. Fisher, E.A. Graham, J. Abatzoglou, B.E. Wilson, } \\
\text { D.D. Breshears, G.M. Henebry, J.M. Hanes, and L. Liang. 2009. Tracking the rhythm of the seasons } \\
\text { in the face of global change: phenological research in the } 21 \text { st century. Frontiers in Ecology and the } \\
\text { Environment 7(5): } 253-260 \text {. }\end{array}$ \\
\hline Abstract & $\begin{array}{l}\text { Morisette, J.T., F. Gao, B. Tan, R. Wolfe, C. Jarnevich, S. Jumar, A. Swanson, P. Ma, N. Benson, A. } \\
\text { Rodman, C. McClurre, P. Lineback, T. Caprio, A. Demetry, D. Abendroth, and K. McCloskey. } 2009 . \\
\text { Using satellite-based phenology data for invasive weed species habitat modeling. Abs. In: Proceed- } \\
\text { ings, } 2009 \text { US-IALE 24th Annual Landscape Ecology Symposium: Landscape Patterns and } \\
\text { Ecosystem Processes, April 12-16, Snowbird. UT. International Association of Landscape Ecology. } \\
\text { p. } 109 .\end{array}$ \\
\hline Pages in Book & $\begin{array}{l}\text { Rodda, G.H. 2009. Marianas, Biology. In: R. Gillespio and D. Clague (eds.). Encyclopedia of Isl- } \\
\text { ands. Berkeley, CA: University of California Press. p. 593-597. }\end{array}$ \\
\hline Journal Article & $\begin{array}{l}\text { Rodda, G.H., C.S. Jarnevich, and R.N. Reed. 2009. What parts of the US mainland are climatically } \\
\text { suitable for invasive alien pythons spreading from Everglades National Park? Biological Invasions } \\
\text { 11(2): } 241-252 .\end{array}$ \\
\hline Pages in Book & $\begin{array}{l}\text { Rodda, G.H., and C.L. Tyrrell. 2008. Introduced species that invade and species that thrive in town: } \\
\text { are these two groups cut from the same cloth? In: J.C. Mitchell, R.E. Jung Brown, and B. Bartholo- } \\
\text { mew (eds.). Urban Herpetology: Herpetological Conservation, Volume 3. Salt Lake City, UT: } \\
\text { Society for the Study of Amphibians and Reptiles. p. 327-341. }\end{array}$ \\
\hline Journal Article & $\begin{array}{l}\text { Tyrrell, C.L., M.T. Christy, G.H. Rodda, A.A. Yackel Adams, A.R. Ellingson, J.A. Savidge, K. } \\
\text { Dean-Bradley, and R. Bischof. 2009. Evaluation of trap capture in a geographically closed popula- } \\
\text { tion of brown treesnakes on Guam. Journal of Ecological Applications 46(1): 128-135. }\end{array}$ \\
\hline Journal Article & $\begin{array}{l}\text { Vincent, K.R., J.M. Friedman, and E.R. Griffin. 2009. Erosional consequence of saltcedar control. } \\
\text { Environmental Management 44(2): 218-227. }\end{array}$ \\
\hline Journal Article & $\begin{array}{l}\text { Wiewel, A.S., A.A. Yackel Adams, and G.H. Rodda. 2009. Evaluating abundance estimate precision } \\
\text { and the assumptions of a count-based index for small mammals. Journal of Wildlife Management } \\
73(5): 761-771 \text {. }\end{array}$ \\
\hline Journal Article & $\begin{array}{l}\text { Wiewel, A.S., A.A. Yackel Adams, and G.H. Rodda. 2009. Distribution, density, and biomass of in- } \\
\text { troduced small mammals in the southern Mariana Islands. Pacific Science 63(2): 205-222. }\end{array}$ \\
\hline
\end{tabular}




\section{Status and Trends of Biological Resources (ST)}

USGS Scientific
Investigations Re-
port

Preric

Journal Article

\begin{tabular}{|l|}
\hline Pages in Book \\
\hline Pages in Book \\
\hline $\begin{array}{l}\text { USGS Open-File } \\
\text { Report }\end{array}$ \\
\hline
\end{tabular}

\begin{tabular}{|l|}
\hline Journal Article \\
\hline Journal Article \\
\hline $\begin{array}{l}\text { Pages in Proceed- } \\
\text { ings }\end{array}$ \\
\hline
\end{tabular}

\begin{tabular}{|l|l}
\hline \multirow{2}{*}{ Abstract } & S \\
& Tournal Article \\
\hline & S \\
\hline
\end{tabular}

\begin{tabular}{l|l}
\hline USGS Open-File \\
Report
\end{tabular}

\begin{tabular}{|l|l|}
\hline \multirow{2}{*}{ Abstract } & 2009-1030.66 p. \\
\hline $\begin{array}{l}\text { Stanley, T.R. and W.D. Newmark. 2008. Estimating length of avian incubation and nesting stages for } \\
\text { afrotropical forest birds from interval censored nest records. Abs. In: Proceedings, The Wildlife So- } \\
\text { ciety 15th Annual Conference, November 8-12, 2008, Miami, FL. Bethesda, MD: The Wildlife } \\
\text { Society. p. 1. }\end{array}$ \\
\hline Report
\end{tabular}

Bowen, Z.H., C.L. Aldridge, P.J. Anderson, G.W. Chong, M.A. Drummond, C. Homer, R.C. Johnson, M.J. Kauffman, S.T. Knick, J.J. Kosovich, K.A. Miller, T. Owens, S. Shafer, and M.J. Sweat. 2009. U.S. Geological Survey Science Strategy for the Wyoming Landscape Conservation Initiative: Scientific Investigations Report 2008-5195. 26 p.

Carlisle, J.D., S.K. Skagen, B.E. Kus, C. van Riper III, K.L. Paxton, and J.F. Kelly. 2009. Landbird migration in the American West: Recent progress and future research directions. The Condor 111(2): 211-225.

Douglas, A.J. 2009. Protecting, restoring and conserving renewable resources: The role of the social sciences. In: J.B. Aronoff (ed.). Handbook of Nature Conservation: Global, Environmental and Economic Issues. New York: Nova Science Publishers. p. 91-117.

Douglas, A.J. 2009. The cost and benefits of developing sustainable use strategies and restoration activities for corals and coral reefs. In: T.B. Davin and A.P. Brannet (eds.). Coral Reefs: Biology, Threats and Restoration. New York: Nova Science Publishers. Chapter 3.

Montag, J.M. and H.M. Stinchfield. 2009. Moosehorn National Wildlife Refuge Workbook Summary: U.S. Geological Survey Open-File Report 2009-1167. 28 p.

O'Shea, T.J. 2008. The urban whale: North Atlantic right whales at the crossroads, by S.D. Kraus and R.M. Rolland (eds.). [Book Review]. Journal of Mammalogy 89(5): 1328.

Ponds, P.D. 2009. Race, Space, and Riots in Chicago, New York, and Los Angeles [Book Review]. The Social Science Journal 46(1): 228-230.

Ruth, J.M. and K.V. Rosenberg. 2009. Partners in Flight research needs assessment summary. In:

T.D. Rich, C. Arizmendi, D. Demarest, and C. Thompson (eds.). Proceedings of the 4th International Partners in Flight Conference, 13-16 February 2008. McAllen, TX. Partners in Flight. p. 23-33.

Schorr, R.A., L.E. Ellison, and P.M. Lukacs. 2009. Bat banding: Trials and tribulations for estimating survival over a landscape scale. Abs. In: Western Bat Working Group Biennial Meeting, Austin TX. Rapid City, SD: Western Bat Working Group. p. 1.

Scott, M.L., P.L. Nagler, E.P. Glenn, C. Valdes-Casillas, J.A. Erker, E.W. Reynolds, P.B. Shafroth, E.G. Limon, and C.L. Jones. 2009. Assessing the extent and diversity of riparian ecosystems in Sonora, Mexico. Biodiversity and Conservation 18(2): 247-269.

Sexton, N.R., N. Burkardt, M.E. Swann, and S.C. Stewart. 2009. Stakeholder evaluation for Canaan Valley National Wildlife Refuge: Completion Report: U.S. Geological Survey Open-File Report 2009-1030. 66 p.

Stanley, T.R. and W.D. Newmark. 2008. Estimating length of avian incubation and nesting stages for 作 ciety 15th Annual Conference, November 8-12, 2008, Miami, FL. Bethesda, MD: The Wildlife Stinchfield, H.M., L. Koontz, and N.R. Sexton. 2009. Social and economic considerations for coastal and watershed restoration in the Puget Sound, Washington: A literature review: U.S. Geological SurValdez, E.W., C.M. Ritzi, and J.O. Whitaker, Jr. 2009. Ectoparasites of the occult bat, Myotis occulus (Chiroptera: Vespertilionidae). Western North American Naturalist 69(3): 364-370.

Valdez, E.W., K. Geluso, J. Foote, G. Allison-Kosior, and D.M. Roemer. 2009. Spring and winter records of the eastern pipistrelle (Perimyotis subflavus) in southeastern New Mexico. Western North Widife:

\section{Wildlife: Terrestrial and Endangered Resources (WTR)}




\begin{tabular}{|c|c|}
\hline Journal Article & $\begin{array}{l}\text { alisher, C.H., K.V. Holmes, S.R. Dominguez, T. Schountz, and P. Cryan. 2008. Bats prove to be } \\
\text { ch reservoirs for emerging viruses. Microbe 3(11): 521-528. }\end{array}$ \\
\hline Abstract & $\begin{array}{l}\text { Cryan, P.M. 2008. Hypothesized causes of White Nose Syndrome. Abs. In: } 38 \text { th Annual North } \\
\text { American Symposium on Bat Research, October 22-25, 2008, Scranton, PA. North American Socie- } \\
\text { ty for Bat Research. p. } 15 \text {. }\end{array}$ \\
\hline Abstract & $\begin{array}{l}\text { Cryan, P.M. 2008. Why did the tree bat cross the turbine? Abs. In: 38th Annual North American } \\
\text { Symposium on Bat Research, October 22-25, 2008, Scranton, PA. North American Society for Bat } \\
\text { Research. p. 1. }\end{array}$ \\
\hline Abstract & $\begin{array}{l}\text { Cryan, P.M. 2009. Bat migration and wind turbines. Abs. In: Proceedings, 1st International Sympo- } \\
\text { sium on Bat Migration January 16-18, 2009, Berlin, Germany. Berlin: Leibniz Institute for Zoo and } \\
\text { Wildlife Research. p. } 4 \text {. }\end{array}$ \\
\hline $\begin{array}{l}\text { USGS Open-File } \\
\text { Report }\end{array}$ & $\begin{array}{l}\text { Ellison, L.E. 2008. Summary and analysis of the U.S. Government Bat Banding Program: U.S. Geo- } \\
\text { logical Survey Open-File Report 2008-1363. } 117 \text { p. }\end{array}$ \\
\hline Journal Article & $\begin{array}{l}\text { Farmer, A., B.S. Cade, and J. Torres-Dowall. 2008. Fundamental limits to the accuracy of deuterium } \\
\text { isotopes for identifying the spatial origin of migratory animals. Oecologia 158(2): 183-192. }\end{array}$ \\
\hline Journal Article & $\begin{array}{l}\text { Farmer, A.H. 2008. "Anchoring" and research priorities: Factors that depress bird population esti- } \\
\text { mates? The Auk 125(4): } 980-983 .\end{array}$ \\
\hline Journal Article & $\begin{array}{l}\text { cobs, B.F., W.H. Romme, and C.D. Allen. 2008. Mapping "old" versus "young" pinon-juniper } \\
\text { ands with a predictive topo-climatic model. Ecological Applications 18(7): 1627-1641. }\end{array}$ \\
\hline Journal Article & $\begin{array}{l}\text { Muths, E., B. Spurre Pedersen, and F. Spurre Pedersen. 2009. How relevant is opportunistic Bd sam- } \\
\text { pling: Are we ready for the big picture? Herpetological Review 40(2): 183-184. }\end{array}$ \\
\hline Abstract & $\begin{array}{l}\text { Muths, E., D.S. Pilliod, and R.D. Scherer. 2009. Survival with disease: Toad populations in the } \\
\text { Rocky Mountains. Abs. In: Proceedings, Joint Meeting of Ichthyologists and Herpetologists, July 22- } \\
\text { 27, Portland, OR. Miami, FL: American Society of Ichthyologists and Herpetologists. p. 1. }\end{array}$ \\
\hline Abstract & $\begin{array}{l}\text { Oyler-McCance, S.J., C.A. Stricker, J. St. John, C.E. Braun, G.T. Wann, and C.L. Aldridge. } 2009 . \\
\text { Investigating the potential genetic consequences of climate change on White-tailed Ptarmigan. Abs. } \\
\text { In: Proceedings, The Wildlife Society 16th Annual Conference. Bethesda, MD: The Wildlife Socie- } \\
\text { ty. p. } 1 .\end{array}$ \\
\hline Report & $\begin{array}{l}\text { yle, P., S.L. Jones, and J.M. Ruth. 2008. Molt and aging criteria for four North American grassland } \\
\text { ssserines. Fish and Wildlife Service Biological Technical Publication BTP-R6011-2008. } 19 \text { p. }\end{array}$ \\
\hline $\begin{array}{l}\text { USGS Techniques } \\
\text { and Methods Re- } \\
\text { port }\end{array}$ & $\begin{array}{l}\text { Ransom, J.I. and B.S. Cade. 2009. Quantifying equid behavior: A research ethogram for free- } \\
\text { roaming feral horses: U.S. Geological Survey Techniques and Methods Report 2-A9. } 23 \text { p. }\end{array}$ \\
\hline Journal Article & $\begin{array}{l}\text { cchini, D. and B.S. Cade. 2008. Quantile regression applied to spectral distance decay. IEEE } \\
\text { oscience and Remote Sensing Letters 5(4): 640-643. }\end{array}$ \\
\hline $\begin{array}{l}\text { USGS Scientific } \\
\text { Investigations Re- } \\
\text { port }\end{array}$ & $\begin{array}{l}\text { Roelle, J.E. and J.I. Ransom. 2009. Injection-site reactions in wild horses (Equus caballus) receiving } \\
\text { an immunocontraceptive vaccine: U.S. Geological Survey Scientific Investigations Report 2009- } \\
5038.15 \text { p. }\end{array}$ \\
\hline USGS Fact Sheet & $\begin{array}{l}\text { Ruth, J.M., J.J. Buler, R.H. Diehl, and R.S. Sojda. 2008. Management and research applications of } \\
\text { long-range surveillance radar data for birds, bats, and flying insects: U.S. Geological Survey Fact } \\
\text { Sheet 2008-3095. } 4 \text { p. }\end{array}$ \\
\hline USGS Fact Sheet & $\begin{array}{l}\text { Rye, R.O., C.A. Johnson, G.P. Landis, A.H. Hofstra, P. Emsbo, C.A. Stricker, A.G. Hunt, and B.G. } \\
\text { Rusk. 2008. Isotope and Chemical Methods in Support of the U.S. Geological Survey Science Strat- } \\
\text { egy, 2003-2008: U.S. Geological Survey Fact Sheet 2008-3083. } 6 \text { p. }\end{array}$ \\
\hline Pages in Report & $\begin{array}{l}\text { Shanks, III, W.C.P., E.C. Hellgren, C. Stricker, P.A. Gemery-Hill, and D.P. Onorato. 2008. Stable } \\
\text { Isotope and Trace Element Studies of Black Bear Hair, Big Bend Ecosystem, Texas and Mexico. In: } \\
\text { J.E. Gray and W.R. Page (eds.). Geological, Geochemical, and Geophysical Studies by the U.S. Geo- } \\
\text { logical Survey in Big Bend National Park, Texas: U.S. Geological Survey Circular 1327. p. 77-84. }\end{array}$ \\
\hline
\end{tabular}




\begin{tabular}{|l|l|}
\hline Journal Article & $\begin{array}{l}\text { Torres-Dowdall, J., A.H. Farmer, E.H. Bucher, R.O. Rye, and G. Landis. 2009. Population variation } \\
\text { in isotopic composition of shorebird feathers: Implications for determining molting grounds. Water- } \\
\text { birds 32(2): 300-310. }\end{array}$ \\
\hline Journal Article & $\begin{array}{l}\text { Valdez, E.W. and P.M. Cryan. 2009. Food habits of the hoary bat (Lasiurus cinereus) during spring } \\
\text { migration through New Mexico. Southwestern Naturalist 54(2): 195-200. }\end{array}$ \\
\hline Journal Article & $\begin{array}{l}\text { Weller, T.J., P.M. Cryan, and T.J. O’Shea. 2009. Broadening the focus of bat conservation and re- } \\
\text { search in the USA for the 21st century. Endangered Species Research 8(1-2): 129-145. }\end{array}$ \\
\hline Journal Article & $\begin{array}{l}\text { Wimsatt, J. and D.E. Biggins. 2009. A review of plague persistence with special emphasis on fleas. } \\
\text { Journal of Vector Borne Diseases 46(2): 85-99. }\end{array}$ \\
\hline
\end{tabular}




\section{Appendix 2: Other FORT Products Delivered in FY 2009}

\begin{tabular}{|c|c|}
\hline Product Type & Citation \\
\hline \multicolumn{2}{|r|}{ Biological Informatics (BIO) } \\
\hline Web application & $\begin{array}{l}\text { Alaska Climate Monitoring, v. 1.0. May 2009. Real-time climate charting, mapping, and data presen- } \\
\text { tation from Arctic telemetry sites. }\end{array}$ \\
\hline Web application & $\begin{array}{l}\text { Invasive Species Modeling and Assessment System, v. 2.0, March 2009. Real time modeling of po- } \\
\text { tential suitable habitat for invasive species, with full model metadata and results output as text and } \\
\text { NetCDF. }\end{array}$ \\
\hline $\begin{array}{l}\text { Web science fea- } \\
\text { ture }\end{array}$ & $\begin{array}{l}\text { Kern, T. and G. Montgomery. December 2008. New Web application supports reclamation } \\
\text { decisionmaking for the Jonah Natural Gas Field. http://www.fort.usgs.gov/JIO/. }\end{array}$ \\
\hline Web application & $\begin{array}{l}\text { Jonah Infill Data Management System, v. 1.0. December 2008. Initial release of the JIDMS, extensive } \\
\text { spatial data management and tracking, reclamation status tracking. }\end{array}$ \\
\hline Web application & $\begin{array}{l}\text { Jonah Infill Data Management System, v. 1.1. January 2009. Operator tutorials, operator-specific por- } \\
\text { tal pages, instantaneous feedback of reclamation site status. }\end{array}$ \\
\hline Web application & $\begin{array}{l}\text { Jonah Infill Data Management System, v. } 1.2 \text {. February 2009. Image library and document manage- } \\
\text { ment system integration. }\end{array}$ \\
\hline Web application & $\begin{array}{l}\text { Jonah Infill Data Management System, v. 1.3. April 2009. Addition of ad hoc reports, operator per- } \\
\text { formance monitoring, and multitheme interactive mappers. }\end{array}$ \\
\hline Web application & $\begin{array}{l}\text { Jonah Infill Data Management System, v. 1.4 . May 2009. Air quality support added, operator and } \\
\text { field air quality reports. }\end{array}$ \\
\hline Web application & $\begin{array}{l}\text { Jonah Infill Data Management System, v. 1.5. July 2009. Mitigation support added, interactive project } \\
\text { area mapper with attribute editing capability. }\end{array}$ \\
\hline $\begin{array}{l}\text { Web science fea- } \\
\text { ture }\end{array}$ & $\begin{array}{l}\text { Wilson, J.T. 2009. Following Sirenia's song: The meritorious journey of research zoologist Thomas J. } \\
\text { O'Shea. http://www.fort.usgs.gov/OShea/. }\end{array}$ \\
\hline $\begin{array}{l}\text { Web science fea- } \\
\text { ture }\end{array}$ & $\begin{array}{l}\text { Wilson, J.T. 2009. FORT scientist's name in NEON: Helping to light the way for understanding eco- } \\
\text { logical change. http://www.fort.usgs.gov/NEON/. }\end{array}$ \\
\hline \multicolumn{2}{|r|}{ Enterprise Information (ENT) } \\
\hline Web application & $\begin{array}{l}\text { MyUSGS, v. 3.5. November 2008. Suite of data management for People, Locations, Organizations } \\
\text { and Teams; editing of Person, Location, Organization and Team records; self-editing of Personal Da- } \\
\text { ta; management of data for both USGS and non-USGS people and organizations; support for multiple } \\
\text { locations; more authority for community managers. }\end{array}$ \\
\hline Web application & $\begin{array}{l}\text { MyUSGS, v. 3.6. February 2009. New Team Data Provider; new Organization Data Provider; new } \\
\text { public view of public myUSGS Person data; support for creating/managing Service Accounts; altered } \\
\text { user authentication and authorization workflow; performance optimization. }\end{array}$ \\
\hline Web application & $\begin{array}{l}\text { MyUSGS, v. 3.7. February 2009. Implemented Alfresco } 3 \text { (upgraded document management system } \\
\text { and repository); new community creation workflow and increase capability for community managers } \\
\text { (add features to the community and sponsor new users). }\end{array}$ \\
\hline
\end{tabular}




\begin{tabular}{|c|c|}
\hline Web application & $\begin{array}{l}\text { MyUSGS, v. 3.8. February 2009. Integrated the JIRA issue tracking system with the myUSGS suite } \\
\text { of tools and allowed community managers to add issue tracking to their community toolkit; enabled } \\
\text { full single-signon within all myUSGS and partner applications, as well as user and group synchroniza- } \\
\text { tion; myUSGS Feature/Request (Issue) form now redirects to Issue Tracking system; Alfresco } \\
\text { automated image processing and Open Office integration; new Public Providers for People, Organiza- } \\
\text { tions, and Teams and their Locations; established weekly myUSGS WebEx Sessions. }\end{array}$ \\
\hline Web application & $\begin{array}{l}\text { MyUSGS, v. 3.9. February 2009. Added support for personal information changes and visibility into } \\
\text { request status; allows managers to view pending requests. }\end{array}$ \\
\hline Web application & $\begin{array}{l}\text { MyUSGS, v. 3.10. July 2009. Added support for Organizations in myUSGS - identification, services, } \\
\text { search, and initiation; added new fields to the Public services provider. }\end{array}$ \\
\hline Web application & $\begin{array}{l}\text { MyUSGS, v. 3.11. September 2009. Added support for the ScienceBase Catalog; full framework up- } \\
\text { grade; full security design upgrade. }\end{array}$ \\
\hline Systems support & $\begin{array}{l}\text { Central Region Application Hosting Platform (CRAHC), FY2009. Implemented } 42 \text { virtual application } \\
\text { servers and } 42 \mathrm{~TB} \text { of storage for } 24 \text { applications; averaged over } 500 \mathrm{~K} \text { secure page views per month } \\
\text { and } 1.8 \mathrm{M} \text { database transactions/month. }\end{array}$ \\
\hline Web application & $\begin{array}{l}\text { SCIM (Simple Content Information Management), v. 1.7. October 2008. Web-based data/content } \\
\text { management and distribution system; upgraded content editor and added new tagging model. }\end{array}$ \\
\hline Web application & SCIM (Simple Content Information Management), v. 1.8. March 2009. Added image handling. \\
\hline Web application & $\begin{array}{l}\text { PLOT (People, Locations, Organizations, Teams), v.1.0. December 2008. Implemented a set of direc- } \\
\text { tory web services, tied to user inputs and edits on the myUSGS site. This utility allows partner web } \\
\text { sites to access web services of Public or Secure staff, facility, team, and organization information. } \\
\text { PLOT consolidates and allows correction of information stored in six different locations. }\end{array}$ \\
\hline Web application & $\begin{array}{l}\text { ScienceBase Footprinter, v. 1.0. August 2009. Modular FLEX-based spatial data handling interface. } \\
\text { Acts as front end for a number of project and data cataloging efforts, including maps.usgs.gov, da- } \\
\text { ta.usgs.gov, and www.wlci.gov. }\end{array}$ \\
\hline \multicolumn{2}{|r|}{ Fisheries: Aquatic and Endangered Resources (FAER) } \\
\hline $\begin{array}{l}\text { Decision support } \\
\text { system }\end{array}$ & $\begin{array}{l}\text { Application of the Hydroecological Integrity Assessment Process for Missouri Streams. August } 2009 . \\
\text { Decision-support system. }\end{array}$ \\
\hline \multicolumn{2}{|r|}{ Status and Trends of Biological Resources (ST) } \\
\hline Web application & $\begin{array}{l}\text { WLCI-PAMS (Wyoming Landscape Conservation Initiative Project and Activity Mapping System), } \\
\text { v. } 1.0 \text { November 2008. Web-based map and attribute distribution system. }\end{array}$ \\
\hline Web application & $\begin{array}{l}\text { WLCI (Wyoming landscape Conservation Initiative) Project and Partner Tracking, v. 1.0. March } \\
\text { 2009. Data management. }\end{array}$ \\
\hline Web site & $\begin{array}{l}\text { Muths, E. 2008. Native boreal toads released into Rocky Mountain National Park. } \\
\text { http://armi.usgs.gov/feature_boreal_toad.asp. }\end{array}$ \\
\hline \multicolumn{2}{|r|}{ Wildlife: Terrestrial and Endangered Resources (WTR) } \\
\hline Web application & $\begin{array}{l}\text { SHRIMP (Species-Habitat Requirements Information Management System), v. 2.0. August 2009. Da- } \\
\text { ta management. }\end{array}$ \\
\hline $\begin{array}{l}\text { Web science fea- } \\
\text { ture }\end{array}$ & $\begin{array}{l}\text { Cryan, P.M. 2009. White-nose syndrome threatens the survival of hibernating bats in North America. } \\
\text { http://www.fort.usgs.gov/WNS/. }\end{array}$ \\
\hline
\end{tabular}




\section{Appendix 3: Accomplishments and Activities of FORT Staff in FY 2009}

\section{Staff Appointments and Committee Assignments}

1. Craig D. Allen, Appointed Member, Council for Ecosystem Science in USGS.

2. Jill Baron, Editor-in-Chief, Issues in Ecology.

3. Jill Baron, Associate Editor, Ecological Applications.

4. Jill Baron, Chairperson, Fort Collins Science Center Science Advisory Board.

5. Jill Baron, Co-Director, Powell Center for Analysis and Synthesis.

6. Jill Baron, Member, USGS Global Change Program Science Advisory Council.

7. Jill Baron, Nominee for the office of President, American Society for Limnology and Oceanography.

8. Jill Baron, Member, Science Executive Committee NEON Domains 10 and 13.

9. Jill Baron, Guest Editor for special feature on adaptation options for protected-area natural resources, Environmental Management.

10. Dean Biggins, Member, APHIS Plague and Tularemia Advisory Panel.

11. Dean Biggins, Member, Black-footed Ferret Recovery Implementation Team, Conservation Subcommittee.

12. Lea' R. Bonewell, Member, Western Bat Working Group.

13. Lea' R. Bonewell, Secretary and Member, Colorado Bat Working Group.

14. Lea' R. Bonewell, Board Member, Membership Committee Chair, and Conservation Committee, Colorado Bat Society.

15. Lea' R. Bonewell, Member, Colorado White Nose Syndrome Group.

16. Lea' R. Bonewell, Invited Referee, Herpetological Conservation and Biology.

17. Brian S. Cade, Editorial Board, Frontiers in Ecology and the Environment.

18. Paul Cryan, Chair, Bats and Wind Energy Cooperative Science Committee.

19. Paul Cryan, Member, White Nose Syndrome Science Strategy Committee.

20. Paul Cryan, Associate Editor, Northwestern Naturalist.

21. Jeff Morisette, Member, User Working Group, USGS Earth Resources Observation and Science Center Land Processes Distributed Active Archive Center.

22. Jeff Morisette, Member, National Ecological Observatory Network Operations Working Group.

23. Jeff Morisette, Session Moderator, "Remote Sensing of Landscapes II" and judge of three student presentations, U.S. International Association of Landscape Ecology Annual Meeting.

24. Erin Muths, Associate Editor, Animal Conservation.

25. Erin Muths, Board of Trustees, Herpetologists' League. 
26. Erin Muths, Steering Committee and 2009 Meeting Planning Committee Member, Southwest Partners in Amphibian and Reptile Conservation.

27. Erin Muths, Advisory Board Member, Save The Frogs!

28. Tom O'Shea, Committee Member, Marine Mammals Committee, Conservation Awards Committee, Legislation and Regulations Committee, American Society of Mammalogists.

29. Sara Oyler-McCance, Editorial Board, Wilson Journal of Ornithology.

30. Sara Oyler-McCance, Member, White Nose Syndrome Genetics Working Group.

31. Cindy Ramotnik, Member, New Mexico Endemic Salamander Team.

32. Cindy Ramotnik, Associate Editor, Collection Forum.

33. Cindy Ramotnik, Member, Conservation, Documentation, Membership, and Publication Committees. Society for the Preservation of Natural History Collections.

34. Jason Ransom, Member, Species Survival Commission, Equid Specialist Group, International Union of Conservation and Nature.

35. Robert Reed, Associate Editor, Herpetological Review.

36. Robert Reed, Vertebrate Subcommittee and Member, Interagency Committee on Invasive Terrestrial Animals and Pathogens (ITAP, a Federal multi-agency group).

37. Robert Reed, Graduate Advisor, Ph.D. Committee, University of Nevada-Las Vegas.

38. Robert Reed, Invited Referee, Biological Conservation, Animal Conservation, and Journal of Herpetology.

39. Robert Reed, Judges Board, Seibert Award for Outstanding Graduate Presentation, 2009 Joint Meeting of Ichthyologists and Herpetologists.

40. Gordon Rodda, Member, Mariana Crow Recovery Team.

41. Gordon Rodda, Member, Guam Kingfisher Recovery Team.

42. Gordon Rodda, Graduate Advisor, M.S. Committee, Colorado State University.

43. Janet Ruth, Steering Committee Member, New Mexican Avian Conservation Partners (former New Mexico Partners in Flight).

44. Janet Ruth, Board Member, New Mexico Ornithological Society.

45. Janet Ruth, Research Working Group Chair and Member, National Implementation Committee, International Science Committee, National Federal Committee, Partners in Flight.

46. Jeff Schafer, Member, USGS Information Technology Security Operations Team (ITSOT).

47. Susan Skagen, Co-Chair, Program for Regional and International Shorebird Monitoring, U.S. Shorebird Conservation Plan.

48. Susan Skagen, Member, Monitoring Subcommittee, North American Bird Conservation Initiative (NABCI).

49. Susan Skagen, Board of Directors, Cooper Ornithological Society.

50. Sarah Spaulding, Lead Organizer, 2009 North American Diatom Symposium.

51. Sarah Spaulding, Advisory Council Member, International Society for Diatom Research.

52. Sarah Spaulding, Research Scientist II, Member, INSTAAR Directorate, Institute for Arctic and Alpine Research, University of Colorado. 
53. Sarah Spaulding, Member, Science Advisory Panel on Aquatic Invasive Species, Grand Teton National Park.

54. Sarah Spaulding, Monday INSTAAR Seminar Series Organizer (fall 2008 and spring 2009), Institute for Arctic and Alpine Research, University of Colorado.

55. James Stanford, Member, Pacific Invasives Learning Network.

56. James Stanford, Secretary and Member, Guam Invasives Species Advisory Committee.

57. James Stanford, USGS liaison, Local Interagency Networking Committee.

58. Thomas Stohlgren, Editorial Board, Ecology, Ecological Monographs, and Ecological Applications.

59. Thomas Stohlgren, USGS Liaison, National Ecological Observation Network (NEON).

60. Ernie Valdez, Co-Chair, New Mexico Bat Working Group.

61. Ernie Valdez, Member, Student Awards Committee, Southwestern Association of Naturalists.

62. David Walters, Adjunct Professor, Departments of Biological Sciences and Environmental Engineering and Earth Sciences, Clemson University.

63. David Walters, Panel Member, Terns and Plovers, Forage Fish, Geomorphology and Vegetation, and Water Quality; Reviewer, Forage Fish Recovery Plan, Platte River Peer Review Panel.

\section{Invited Presentations}

1. Craig D. Allen, Invited Speaker. "Climate change and the vulnerability of New Mexico forests to altered disturbance processes." New Mexico Forestry and Climate Change Workshop, Albuquerque, N.M., Nov. 2008.

2. Craig D. Allen, Invited Speaker. "Multiple ecosystem state changes since AD 1700 on a semiarid hillslope in New Mexico: Cascading ecohydrological transitions." Society for Range Management, Albuquerque, N.M., Jan. 2009.

3. Craig D. Allen, Invited Speaker. "Warming together, and working together warmly, in the Jemez Mountains" and "Implications of climate change for Jemez Mountains ecosystems." Climate Change Adaptation Workshop for Natural Resource Managers in the Jemez Mountains, Los Alamos, N.M., April 2009.

4. Craig D. Allen, Invited Speaker. “Actuaciones específicas de gestión para la adaptación. El Valor de los Espacios Protegidos en un Escenario de Cambio Global.” Granada, Spain, May 2009.

5. Craig D. Allen, Invited Speaker. "Multiple ecological regime shifts during the past 500 years in a dynamic forest/woodland transition zone in New Mexico." Oral Session Organizer, "Indicators of Regime Shifts in Ecological Systems.” Annual Meeting, Ecological Society of America, Albuquerque, N.M., Aug. 2009.

6. Jill Baron, Invited Speaker. "Water resources in the West: Assessing tradeoffs in a changing climate." Briefing to the U.S. House Committee on Water and Power and the U.S. Senate Committee on Environment and Public Works, sponsored by the Ecological Society of America, Washington, D.C., July 13, 2009.

7. Jill Baron, Invited Field Trip Leader. "Potential impacts of climate change in mountain watersheds." Field trip to Loch Vale watershed long-term ecological research and monitoring site, 
Rocky Mountain National Park for Upper Colorado River Basin Congressional Staff Tour, Sept. 3, 2009.

8. Jill Baron, Invited Speaker. "Climate change impacts to Rocky Mountain National Park." Pre-Senate Field Hearing field trip for Senators John McCain and Mark Udall, Aug. 24, 2009.

9. Jill Baron, Invited Speaker. "CCSP Synthesis and Assessment Product 4.4." Meeting and field trip with Kit Batten, Science Advisor, Rocky Mountain National Park, June 12, 2009.

10. Jill Baron, Invited Speaker. "Ecological effects and the critical load for atmospheric nitrogen deposition in Rocky Mountain National Park." 41st Air Pollution Workshop and Symposium. Fort Collins, Colo., April 2009.

11. Jill Baron, Invited Speaker. "Atmospheric deposition effects on alpine lakes in the Rocky Mountains." The celebration of a centennial of limnology at Cornell University. Ithaca, N.Y., April 2009.

12. Jill Baron, Invited Speaker. "USGS initiatives on climate change adaptation for public lands." Weeds in Space NASA/NPS/USGS Invasive Plants Project meeting, Fort Collins, Colo., April 2009.

13. Jill Baron, Invited Speaker and Session Organizer. "Adaptation options for climate sensitive ecosystems." Looking for Answers at CSU Climate Action Days, Fort Collins, Colo., Feb. 2009.

14. Nina Burkardt and Phadrea Ponds, Invited Speakers. "Social science research and recreation management: What are the connections?" USFWS Spotlight on Science Series, Portland, Oreg., May 2009.

15. Paul Cryan, Invited Speaker. "Control and mitigation of white-nose syndrome in the face of uncertainty." White Nose Syndrome Science Strategy Meeting II, Austin, Tex., May 2009.

16. Paul Cryan, Invited Speaker. "Summary presentation of the Hawaiian Hoary Bat Climate Change Modeling Workshop." Given to stakeholders in State and Federal land management agencies, Hilo, Hawaii, Feb. 2009.

17. Paul Cryan, Invited Speaker. "Bat migration and wind turbines." Plenary address to the 1 st International Symposium on Bat Migration, Berlin, Germany, Jan. 16-18, 2009.

18. Tim Kern, Invited Speaker. "Wyoming Landscape Conservation Initiative (WLCI) GIS data integration.” Council for Data Integration Meeting, Denver, Colo., Sept. 2009.

19. Tim Kern, Invited Speaker. “Assessing reclamation goals: Jonah Infill Data Management System" and "Web-based management of spatial data example: the Jonah Infill Data Management System." Wyoming Landscape Conservation Initiative Science Workshop, Laramie, Wyo., May 2009.

20. Jeff Morisette, Invited Presenter. "Tracking the rhythm of the seasons in the face of global change: Frontiers in phenological research." FOCUS Program, Duke University, Durham, N.C., Nov. 2008.

21. Jeff Morisette, Invited Presenter. "Evaluating the contribution of satellite-based predictor layers in species distribution models." NASA Goddard Space Flight Center seminar series, Greenbelt, Md., Sept. 2009.

22. Sara Oyler-McCance, Invited Speaker. "Investigating long-term variation in the nutritional ecology and genetics of white-tailed ptarmigan." The Wildlife Society Annual Meeting, Monterey, Calif., Sept. 2009. 
23. Phadrea Ponds, Invited Speaker. "Socioeconomic considerations for planning." National USFWS Planning Workshop, National Conservation Training Center, Shepherdstown, W. Va., June 2009.

24. Phadrea Ponds, Invited Speaker. "Ethics, discrimination, and stereotypes in the workplace." USDA/NRCS Area Manager's Meeting, Denver, Colo., Aug. 2009.

25. Robert Reed, Invited Presenter. "Methods development needs for control of Brown Treesnakes." Brown Treesnake Technical Working Group Annual Meeting, Saipan, Commonwealth of the Northern Mariana Islands, April 2009.

26. Robert Reed, Invited Presenter. "Interactions between snake ecology and control tool efficacy in an enclosed population of Brown Treesnakes (Boiga irregularis) on Guam." Snake Ecology Group V, Donnelly, Idaho, July 2009.

27. Robert Reed, Invited Presenter. "Update on giant constrictors.” USFWS South Florida Ecological Services Office, Vero Beach, Fla., Aug. 2009.

28. Robert Reed, Invited Presenter. "Why do people release invasive amphibians and reptiles?" Colorado State University, Ecology of Invasive Species class, Fort Collins, Colo., Sept. 2009.

29. Gordon Rodda, Invited Presenter. "Scale of practical vertebrate control." Colorado State University, Natural Resources Ecology Laboratory seminar series, Fort Collins, Colo., Oct. 2008.

30. Gordon Rodda, Invited Presenter. "Introduction to invasive species policy." Colorado State University, Ecology class, Fort Collins, Colo., Feb. 2009.

31. Gordon Rodda, Invited Presenter. "Climate matching and the potential spread of Burmese Pythons in the United States." All Florida Herpetological Conference, Gainesville, Fla., March 2009.

32. Gordon Rodda, Invited Presenter. "Climate matching and the potential spread of Burmese Pythons in the United States.” Snake Ecology Group V, Donnelly, Idaho, July 2009.

33. Gordon Rodda, Invited Presenter. "Excess density compensation in island herpetofaunal assemblages." University of Colorado Ecology class, Denver, Colo., Sept. 2009.

34. Gordon Rodda, Invited Presenter. "Brown treesnakes and other invasive snakes." Denver Charter School (PS-1), Invasive species class, Denver, Colo., Sept. 2009.

35. Pat Shafroth, Invited Presenter. "Hydrology, fluvial geomorphology, and riparian vegetation: general concepts and a case study from Arizona." Graduate Seminar, Riparian Ecology in the Arid and Mountain West, Colorado State University, Fort Collins, Colo., Oct. 2008.

36. Pat Shafroth, Invited Presenter. "Invasion of riparian ecosystems in western North America by Tamarix: Impacts and restoration approaches." University of Stellenbosch, Department of Conservation Ecology, Stellenbosch, South Africa, Feb. 2009.

37. Pat Shafroth, Invited Presenter. "Alien Tamarix in western North American riparian ecosystems: Invasion process, impacts, control, and restoration." Rhodes University, Grahamstown, South Africa, Feb. 2009.

38. Susan Skagen, Invited Speaker. "En route and breeding birds of dynamic prairie landscapes." Colorado State University Department of Fishery, Wildlife, and Conservation Biology colloquium, Fort Collins, Colo., April 2009. 
39. Sarah Spaulding, Invited Field Trip Leader and Speaker. "Winter limnology." University of Colorado Mountain Research Station field course, Winter Ecology EBIO 4100, Boulder, Colo., Feb. 2009.

40. Sarah Spaulding, Invited Speaker. "Didymosphenia geminata, a diatomic mess...or a normal situation?" U.S. Environmental Protection Agency, Office for Research and Development, Duluth, Minn., April 2009.

41. Sarah Spaulding, Invited Speaker. "Status of stalk-producing diatoms in Grand Teton National Park." Annual Science and Resource Meeting, Grand Teton National Park, Moose, Wyo., Aug. 2009.

42. Sarah Spaulding, Invited Speaker. Laboratory Session Lead, "Didymosphenia geminata." Western Division of the American Fisheries Association Annual Meeting, Albuquerque, N. Mex., May 2009.

43. James Stanford, Invited Presenter. "Invasive species: How secure is your island?" Department of Defense All Hazards Workshop, Colonia, Yap State, Federated States of Micronesia, Dec. 2008.

44. James Stanford, Invited Presenter. "Alien species response in the Pacific." SPC-USDA APHIS Quarantine Training, Guam, April 2009.

45. James Stanford, Invited Presenter. "Early detection and rapid response." Pacific Invasives Learning Network Biosecurity Training, Honolulu, Hawaii, July 2009.

46. James Stanford, Invited Presenter. "Invasive threat: The brown treesnake." Pacific Invasives Learning Network Biosecurity Training, Honolulu, Hawaii, July 2009.

47. James Stanford, Invited Presenter. "Non-native snake response." Pacific Invasives Learning Network Biosecurity Training, Honolulu, Hawaii, July 2009.

48. James Stanford, Invited Presenter. "Response training." Pacific Invasives Learning Network Biosecurity Training, Honolulu, Hawaii, July 2009.

49. James Stanford, Invited Presenter. "Non-native snake response." University of Guam Marine Lab POETS lecture series, Guam, Sept. 2009.

50. James Stanford, Invited Presenter. "Yap: 2008 snake sighting report.” University of Guam Marine Lab POETS lecture series, Guam, Sept. 2009.

51. Thomas Stohlgren, Invited Presenter. “Invasion ecology and NEON: Theory and scale." Institute of Arctic and Alpine Research (INSTAAR) seminar, Boulder, Colo., Dec. 2008.

52. Thomas Stohlgren, Invited Keynote Address. "Invasive species and climate change." North Central Weed Science Society Meeting, Indianapolis, Ind., Dec. 2008.

53. Thomas Stohlgren, Invited Presenter. "Plant invasions in the United States." Midwest Invasive Plant Network (MIPN), Indianapolis, Ind., Dec. 2008.

54. Thomas Stohlgren, Invited as Distinguished Alumnus. "Species invasions from coast to coast." University of California Centennial Series, Davis, Calif., Feb. 2009.

55. Thomas Stohlgren, Invited Keynote Address. "The past, present, and future of plant invasions in the United States." National Weed Awareness Week, Washington, D.C., Feb. 2009.

56. Thomas Stohlgren, Invited Distinguished Ecologist. "Forecasting invasions." Kansas State University, Manhattan, Kans., March 2009. 
57. Thomas Stohlgren, Invited Presenter. "Understanding and managing biological invasions as dynamic processes: Integrating information across space and time." Odum Conference, Rensselaerville, N.Y., April 2009.

58. Thomas Stohlgren, Invited Poster Presenter. "Using Maximum Entropy Modeling in Site Selection." National Ecological Observatory Network (NEON) symposium, Ecological Society of America meeting, Albuquerque, N. Mex., Aug. 2009.

59. Terry Waddle, Invited Lecturer. "River2D Workshop," (a 2-day, hands-on class introducing neophytes to 2-dimensional flow simulation using River2D). Sacramento, Calif., Aug. 2009.

60. David Walters, Invited Speaker. "Are spiders useful indicators for assessing ecosystem recovery and risk from contaminated sediments?" USGS Fort Collins Science Center, Fort Collins, Colo., June 2009.

61. David Walters, Invited Speaker. "Using riparian insectivores as sentinels of aquatic to terrestrial contaminant flux at contaminated sediment sites." Plenary Seminar, Rocky Mountain Chapter, Society of Environmental Toxicology and Chemistry Annual Meeting, Denver, Colo., April 2009.

62. David Walters, Invited Speaker. "Life on the edge: PCB export to riparian ecosystems along Twelvemile Creek and Lake Hartwell.” Departments of Biological Sciences and Environmental Engineering and Earth Sciences, Clemson University, S.C., Feb. 2009.

63. David Walters, Invited Speaker. "The dark side of subsidies: Tracking contaminant export from aquatic to terrestrial ecosystems." Department of Ecology, Montana State University, Bozeman, Mont., Oct. 2008.

64. David Walters, Invited Speaker. "The dark side of subsidies: Tracking contaminant export from aquatic to terrestrial ecosystems." Department of Biology, University of New Mexico, Albuquerque, N.M., Oct. 2008. 


\section{Appendix 4: USGS Science Strategy Directions and Programs Supported by 2009 FORT Scientific and Technical Accomplishments}

Table 1. USGS Science Strategy and USGS Programs and Disciplines supported by 2009 FORT scientific and technical accomplishments. Projects are listed by Biological Resources Discipline and Enterprise Information Programs. Abbreviations used: BIO, Biological Informatics Program; CCSP, U.S. Climate Change Science Program; ECO, Terrestrial, Freshwater, and Marine Ecosystems Program; EIP, Enterprise Information Program; FAER, Fisheries: Aquatic and Endangered Resources Program; GD, Geology Discipline; GEOG, Geography Discipline; GIO, Geospatial Information Office; INV, Invasive Species Program; NBII, National Biological Information Infrastructure; ST, Status and Trends of Biological Resources Program; WRD, Water Resources Discipline; WTR, Wildlife, Terrestrial, and Marine Resources Program.

\begin{tabular}{|c|c|c|c|c|c|c|c|c|c|}
\hline \multirow[b]{2}{*}{ Project by Program } & \multicolumn{6}{|c|}{ Science Direction Addressed } & \multicolumn{2}{|c|}{ Cross-Cutting Science Directions } & \multirow{2}{*}{$\begin{array}{l}\text { Other Pro- } \\
\text { grams with } \\
\text { Goals Met; } \\
\text { Other USGS } \\
\text { Disciplines }\end{array}$} \\
\hline & $\begin{array}{l}\text { Eco- } \\
\text { systems }\end{array}$ & Climate & Energy & Hazards & $\begin{array}{l}\text { Human } \\
\text { Health }\end{array}$ & Water & $\begin{array}{l}\text { Data Integra- } \\
\text { tion }\end{array}$ & $\begin{array}{l}\text { Evolving Tech- } \\
\text { nologies }\end{array}$ & \\
\hline \multicolumn{10}{|l|}{ Biological Informatics } \\
\hline $\begin{array}{l}\text { Identifying Gunnison Sage- } \\
\text { Grouse Nesting Habitat }\end{array}$ & $\checkmark$ & & $\checkmark$ & & & & $\checkmark$ & $\checkmark$ & WTR \\
\hline $\begin{array}{l}\text { Metadata Development and Qual- } \\
\text { ity Control }\end{array}$ & & & & & & & $\checkmark$ & & NBII \\
\hline
\end{tabular}

\section{Enterprise Information}

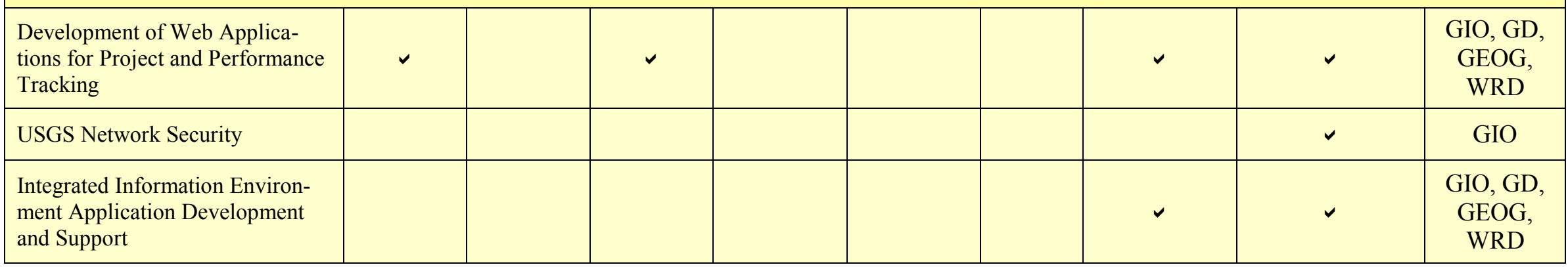




\begin{tabular}{|c|c|c|c|c|c|c|c|c|c|}
\hline \multirow[b]{2}{*}{ Project by Program } & \multicolumn{6}{|c|}{ Science Direction Addressed } & \multicolumn{2}{|c|}{ Cross-Cutting Science Directions } & \multirow{2}{*}{$\begin{array}{l}\text { Other Pro- } \\
\text { grams with } \\
\text { Goals Met; } \\
\text { Other USGS } \\
\text { Disciplines } \\
\end{array}$} \\
\hline & $\begin{array}{l}\text { Eco- } \\
\text { systems }\end{array}$ & Climate & Energy & Hazards & $\begin{array}{l}\text { Human } \\
\text { Health }\end{array}$ & Water & $\begin{array}{l}\text { Data Integra- } \\
\text { tion }\end{array}$ & $\begin{array}{l}\text { Evolving Tech- } \\
\text { nologies }\end{array}$ & \\
\hline \multicolumn{10}{|c|}{ Fisheries: Aquatic and Endangered Resources } \\
\hline $\begin{array}{l}\text { River-Spanning Rock Structures } \\
\text { Research and Design Guidelines }\end{array}$ & $\checkmark$ & & & & & & & $\checkmark$ & ECO \\
\hline $\begin{array}{l}\text { Role of SALMOD in the Klamath } \\
\text { River Secretarial Determination } \\
\text { Process }\end{array}$ & $\checkmark$ & $\checkmark$ & & & & & & $\checkmark$ & WTR \\
\hline $\begin{array}{l}\text { Application of the Hydroecologi- } \\
\text { cal Integrity Assessment Process } \\
\text { for Missouri }\end{array}$ & $\checkmark$ & & $\checkmark$ & & $\checkmark$ & $\checkmark$ & $\checkmark$ & & ECO \\
\hline $\begin{array}{l}\text { Environmental Flow Studies to } \\
\text { Establish a Water Right Benefit }\end{array}$ & $\checkmark$ & & & & & & & & ECO \\
\hline \multicolumn{10}{|l|}{ Invasive Species } \\
\hline $\begin{array}{l}\text { Biological Invasion of Riparian } \\
\text { Ecosystems: Saltcedar and Rus- } \\
\text { sian Olive State-of-the-Science }\end{array}$ & $\checkmark$ & & & & & & $\checkmark$ & & $\begin{array}{l}\text { ECO, } \\
\text { WTR }\end{array}$ \\
\hline $\begin{array}{l}\text { Resource for Advanced Model- } \\
\text { ing: Extending Research on } \\
\text { Invasive Species Habitat Model- } \\
\text { ing and Expanding Our } \\
\text { Partnerships }\end{array}$ & $\checkmark$ & $\checkmark$ & & & & & $\checkmark$ & $\checkmark$ & ECO, ST \\
\hline $\begin{array}{l}\text { Advanced Research on Invasive } \\
\text { Species Habitat Modeling }\end{array}$ & $\checkmark$ & $\checkmark$ & & & & & $\checkmark$ & $\checkmark$ & $\mathrm{ECO}, \mathrm{ST}$ \\
\hline $\begin{array}{l}\text { Control and Prevention of the In- } \\
\text { vasive Brown Treesnake }\end{array}$ & $\checkmark$ & & & $\checkmark$ & $\checkmark$ & & & $\checkmark$ & - \\
\hline $\begin{array}{l}\text { Control of Invasive Giant Con- } \\
\text { strictor Snakes in Florida }\end{array}$ & $\checkmark$ & & & $\checkmark$ & $\checkmark$ & & & $\checkmark$ & WTR \\
\hline
\end{tabular}




\begin{tabular}{|l|c|c|c|c|c|c|c|c|}
\hline \multirow{2}{*}{ Project by Program } & \multicolumn{5}{c|}{ Science Direction Addressed } & \multicolumn{2}{c|}{ Cross-Cutting Science Directions } & $\begin{array}{c}\text { Other Pro- } \\
\text { grams with } \\
\text { Goals Met; } \\
\text { Other USGS } \\
\text { Disciplines }\end{array}$ \\
\cline { 2 - 8 } & $\begin{array}{c}\text { Eco- } \\
\text { systems }\end{array}$ & Climate & Energy & Hazards & $\begin{array}{c}\text { Human } \\
\text { Health }\end{array}$ & Water & $\begin{array}{c}\text { Data Integra- } \\
\text { tion }\end{array}$ & $\begin{array}{c}\text { Evolving Tech- } \\
\text { nologies }\end{array}$ \\
\hline $\begin{array}{l}\text { Control of Invasive Watersnakes } \\
\text { in California }\end{array}$ & - & & & $\checkmark$ & $\checkmark$ & & & $\checkmark$ \\
\hline $\begin{array}{l}\text { Brown Treesnake Rapid Re- } \\
\text { sponse Team Training Workshops }\end{array}$ & & & & $\checkmark$ & $\checkmark$ & & & - \\
\hline
\end{tabular}

\section{Status and Trends of Biological Resources}

\begin{tabular}{|c|c|c|c|c|c|c|c|c|c|}
\hline $\begin{array}{l}\text { The John Wesley Powell Center } \\
\text { for Earth Systems Science Analy- } \\
\text { sis and Synthesis }\end{array}$ & $\checkmark$ & $\checkmark$ & $\checkmark$ & $\checkmark$ & $\checkmark$ & $\checkmark$ & $\checkmark$ & $\checkmark$ & $\begin{array}{c}\text { BIO, ECO, } \\
\text { FAER, ST, } \\
\text { WTR; GD, } \\
\text { GEOG, } \\
\text { GIO, WRD }\end{array}$ \\
\hline $\begin{array}{l}\text { USGS-University Integration of } \\
\text { Natural History Collections }\end{array}$ & $\checkmark$ & $\checkmark$ & $\checkmark$ & & $\checkmark$ & & & $\checkmark$ & BIO, WTR \\
\hline $\begin{array}{l}\text { Using LiDAR to Measure Sage- } \\
\text { brush Structure and Predict } \\
\text { Pygmy Rabbit Site Occupancy }\end{array}$ & $\checkmark$ & & $\checkmark$ & & & & & $\checkmark$ & $\mathrm{ECO}, \mathrm{ST}$ \\
\hline Mapping National Historic Trails & & & & & & & & $\checkmark$ & $\mathrm{BIO}$ \\
\hline $\begin{array}{l}\text { Understanding Conflicts over } \\
\text { Science in Bureau of Reclamation } \\
\text { Decision Processes }\end{array}$ & $\checkmark$ & $\checkmark$ & $\checkmark$ & & & & & & - \\
\hline $\begin{array}{l}\text { Survey of Moderate Resolution } \\
\text { Imagery Users }\end{array}$ & $\checkmark$ & & & & & & & $\checkmark$ & GEOG \\
\hline $\begin{array}{l}\text { Socioeconomic Considerations } \\
\text { for National Wildlife Refuge } \\
\text { Management and Planning }\end{array}$ & $\checkmark$ & $\checkmark$ & & & $\checkmark$ & & & & - \\
\hline $\begin{array}{l}\text { Webinar - An Introduction to the } \\
\text { Fundamentals of Linear Quantile } \\
\text { Regression in R }\end{array}$ & $\checkmark$ & & & & & & & $\checkmark$ & $\begin{array}{l}\text { FAER, } \\
\text { WTR; GD, } \\
\text { WRD }\end{array}$ \\
\hline
\end{tabular}




\begin{tabular}{|c|c|c|c|c|c|c|c|c|c|}
\hline \multirow[b]{2}{*}{ Project by Program } & \multicolumn{6}{|c|}{ Science Direction Addressed } & \multicolumn{2}{|c|}{ Cross-Cutting Science Directions } & \multirow{2}{*}{$\begin{array}{l}\text { Other Pro- } \\
\text { grams with } \\
\text { Goals Met; } \\
\text { Other USGS } \\
\text { Disciplines } \\
\end{array}$} \\
\hline & $\begin{array}{l}\text { Eco- } \\
\text { systems }\end{array}$ & Climate & Energy & Hazards & $\begin{array}{l}\text { Human } \\
\text { Health }\end{array}$ & Water & $\begin{array}{l}\text { Data Integra- } \\
\quad \text { tion }\end{array}$ & $\begin{array}{l}\text { Evolving Tech- } \\
\text { nologies }\end{array}$ & \\
\hline $\begin{array}{l}\text { Negotiation Training for Natural } \\
\text { Resources Professionals }\end{array}$ & & & & & & & & & - \\
\hline \multicolumn{10}{|c|}{ Terrestrial, Freshwater, and Marine Ecosystems } \\
\hline The Western Mountain Initiative & $\checkmark$ & $\checkmark$ & & & & $\checkmark$ & $\checkmark$ & $\checkmark$ & $\begin{array}{l}\text { ST, ECO } \\
\text { (incl. } \\
\text { CCSP and } \\
\text { Global } \\
\text { Change } \\
\text { Research) }\end{array}$ \\
\hline $\begin{array}{l}\text { Sagebrush Ecosystems: Habitat } \\
\text { Mapping, Invasive Plants, and } \\
\text { Grazing Regimes }\end{array}$ & $\checkmark$ & & $\checkmark$ & & & & & $\checkmark$ & $\begin{array}{l}\text { WTR; } \\
\text { GEOG }\end{array}$ \\
\hline \multicolumn{10}{|c|}{ Wildlife and Terrestrial Resources } \\
\hline $\begin{array}{l}\text { Science for Managing America's } \\
\text { Wild Horses and Burros }\end{array}$ & $\checkmark$ & & & & & & & $\checkmark$ & - \\
\hline $\begin{array}{l}\text { Effects of Roads and Traffic on } \\
\text { Wildlife in the Upper Missouri } \\
\text { Breaks National Monument }\end{array}$ & $\checkmark$ & & $\checkmark$ & & & & & $\checkmark$ & $\mathrm{BIO}, \mathrm{ECO}$ \\
\hline $\begin{array}{l}\text { Public Access Management as an } \\
\text { Adaptive Wildlife Management } \\
\text { Tool }\end{array}$ & $\checkmark$ & & & & & & & & $\begin{array}{l}\text { BIO, ST; } \\
\text { GEOG }\end{array}$ \\
\hline White Nose Syndrome in Bats & $\checkmark$ & & & & $\checkmark$ & & & & ST \\
\hline $\begin{array}{l}\text { Plague as a Conservation Threat } \\
\text { to Imperiled Species }\end{array}$ & $\checkmark$ & & & & $\checkmark$ & & & & ECO, ST \\
\hline $\begin{array}{l}\text { The Ecology of Rabies Transmis- } \\
\text { sion in Commensal Bats }\end{array}$ & $\checkmark$ & & & & $\checkmark$ & & & & - \\
\hline
\end{tabular}




\begin{tabular}{|c|c|c|c|c|c|c|c|c|c|}
\hline \multirow[b]{2}{*}{ Project by Program } & \multicolumn{6}{|c|}{ Science Direction Addressed } & \multicolumn{2}{|c|}{ Cross-Cutting Science Directions } & \multirow{2}{*}{$\begin{array}{l}\text { Other Pro- } \\
\text { grams with } \\
\text { Goals Met; } \\
\text { Other USGS } \\
\text { Disciplines }\end{array}$} \\
\hline & $\begin{array}{l}\text { Eco- } \\
\text { systems }\end{array}$ & Climate & Energy & Hazards & $\begin{array}{l}\text { Human } \\
\text { Health }\end{array}$ & Water & $\begin{array}{l}\text { Data Integra- } \\
\text { tion }\end{array}$ & $\begin{array}{l}\text { Evolving Tech- } \\
\text { nologies }\end{array}$ & \\
\hline $\begin{array}{l}\text { Investigating the Long-Term Var- } \\
\text { iation in the Nutritional Ecology } \\
\text { and Genetics of White-Tailed } \\
\text { Ptarmigan: Implication for Effects } \\
\text { of Climate Change on Alpine } \\
\text { Species }\end{array}$ & $\checkmark$ & $\checkmark$ & & & & & & & $\mathrm{ECO}, \mathrm{ST}$ \\
\hline $\begin{array}{l}\text { Symposium on the Ecology of } \\
\text { Plague and Its Effects on Wildlife }\end{array}$ & $\checkmark$ & $\checkmark$ & & & $\checkmark$ & & & & $\mathrm{ECO}, \mathrm{ST}$ \\
\hline
\end{tabular}


Publishing support provided by:

Denver Publishing Service Center

For more information concerning this publication, contact:

Center Director, USGS Fort Collins Science Center

2150 Centre Ave., Bldg. C

Fort Collins, CO 80526-8118

(970) 226-9398

Or visit the Fort Collins Science Center Web site at:

http://www.fort.usgs.gov/ 